\title{
A QUESTION IN ARAB PAINTING: THE IBN AL-SUFI MANUSCRIPT IN TEHRAN AND ITS ART-HISTORICAL CONNECTIONS
}

The manuscript of Ibn al-Sufi's Risālat al-Sūfì fi 'l-kawākib in the Reza Abbasi Museum in Tehran, ${ }^{1}$ which has only quite recently come to the attention of Western scholars, is of great importance for the study of early Arabic manuscript illustration. Specifically, its frontispieces and line drawings of the constellations present very close similarities with the frontispieces and miniatures of the Ibn Bakhtishu' Kitāb $\mathrm{Na}^{c} t$ alhayawān in the British Library ${ }^{2}$ and other well-known manuscripts dated or datable to the early thirteenth century. They thus provide a welcome addition to a small but crucial body of work, and add a further significant element to the comparative study of the evolution of Arab painting.

Although the prime concern here is with the arthistorical issues raised by the illustrations of the Reza Abbasi Museum (henceforth RAM) manuscript, clarity requires that reference be made to textual cvidence relevant to the identity of its author.

The text is the poem that sometimes follows the major astronomical work of al-Sufi. Although the term qașida is also used to describe it, ${ }^{3}$ it properly belongs to the urjüza "genre"--a type of didactic poetry used

27or expository and mnemonic purposes in a wide variety of technical fields, from mathematics and medicine to grammar, history, and music. ${ }^{4}$ Although the Ibn al-Sufi urjuzza follows the order of presentation of the al-Sufi text, it reflects al-Sufi's work only in part. Not only does it ignore all the technical data, it also downplays the "classical" description of the constellation figures, concentrating instead on the Arab element. Nevertheless, the illustrations in the RAM urjūza reflect the al-Sufi manuscripts iconographically: for example, following the Greek tradition, Cassiopeia is portrayed as a woman on a chair, even though, apart from an initial reference to dhāt al-kursī, the urjūza text only deals with the Arab equivalent, a female camel. ${ }^{5}$
Given the close relationship of the urjūza miniatures to those in other early-thirteenth-century manuscripts, we would expect the RAM Risälat al-Süfì fi 'l-kawäkib to be datable to ca. 1220-25. It is therefore suprising that on page 4 we find an inscription giving a date of 554 (1159); were this the actual date of the manuscript, it would require a drastic reappraisal of currently accepted views on the chronology of stylistic evolution.

There are, however, good reasons for thinking it a later interpolation. The first concerns its position. Most reliable dates occur as straightforward statements in manuscript colophons, written in the same hand as the preceding text. In this case the inscription occurs, unexpectedly and oddly, at the very beginning of the text, immediately following the basmala (fig. 2). (The colophon, on page 76 , consists only of blessings and unfortunately provides no information about scribe. date, or provenance [fig. 27].) The inscription also appears odd in the context of the partitions of the text by red lines. Within the same partition as the basmala, it requires two lines of text even though it is written in smaller characters. Were one to assume that it was written contemporaneously with and in the same hand as the rest of the text, one would be entitled to wonder why the scribe did not place it beneath the basmala, perhaps in a separate partition, for even had he compressed the basmala the space left after it would not have been sufficient for the inscription to be completed on the same line and remain within the frame.

However, it is clear that here, as elsewhere, the thin red partition lines were added later, as is shown by the fact that the two internal middle lines terminate neatly (without having been rubbed off) to accommodate a diagonal inscription, later than the main text, which gives the full name of the author (fig. 3). If we visualize how the text would look without the parti- 


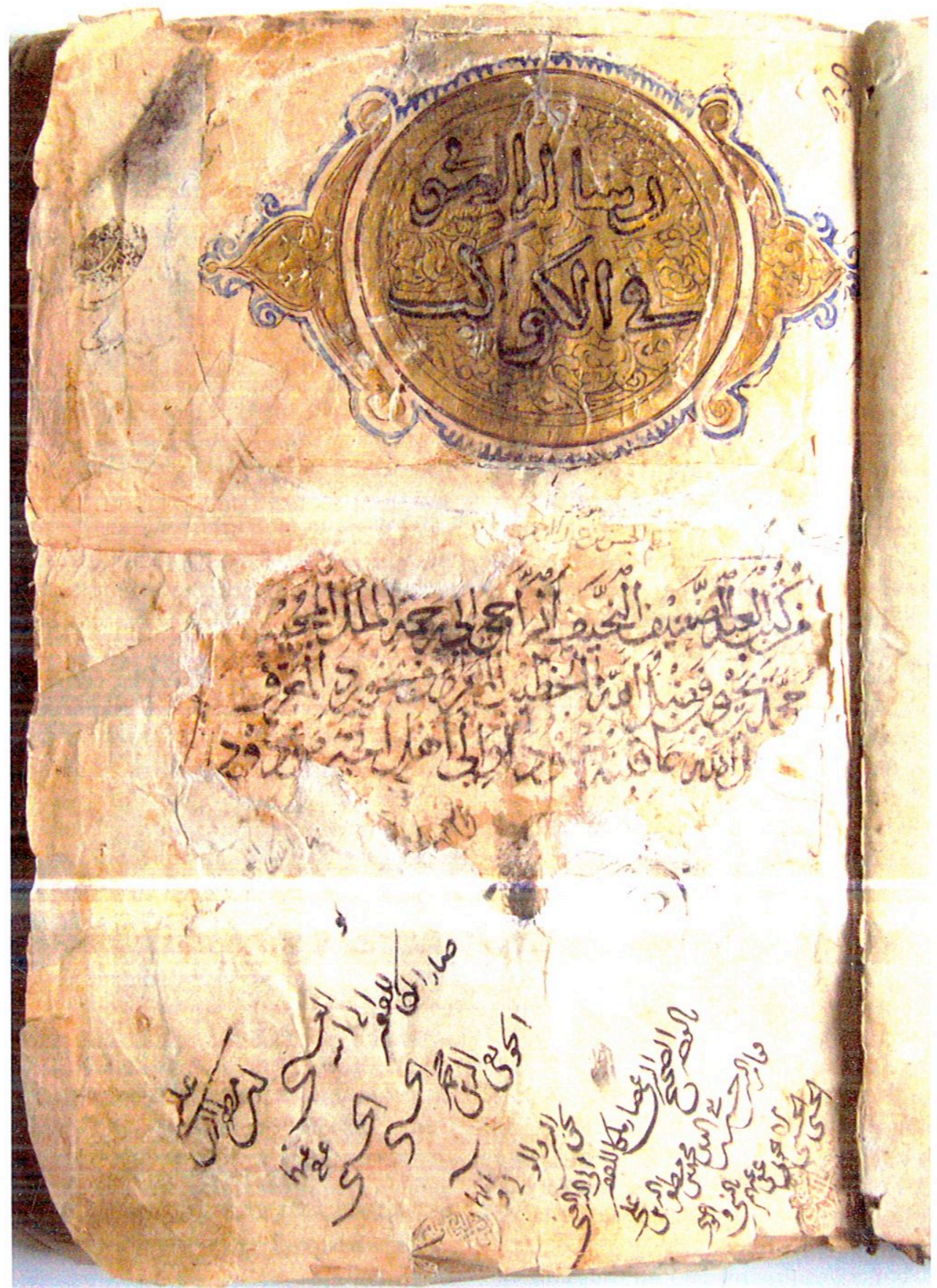

Fig. 1. Opening page with title. From an Ibn al-Sufi Risālat al-Süfi fi 'l-kawäkib, ca. 1220-25, North Jazira(?). Tehran, Reza Abbasi Museum, M. 570, page 1. (Photo: Anna Contadini, courtesy of the Reza Abbasi Museum, Tehran) 


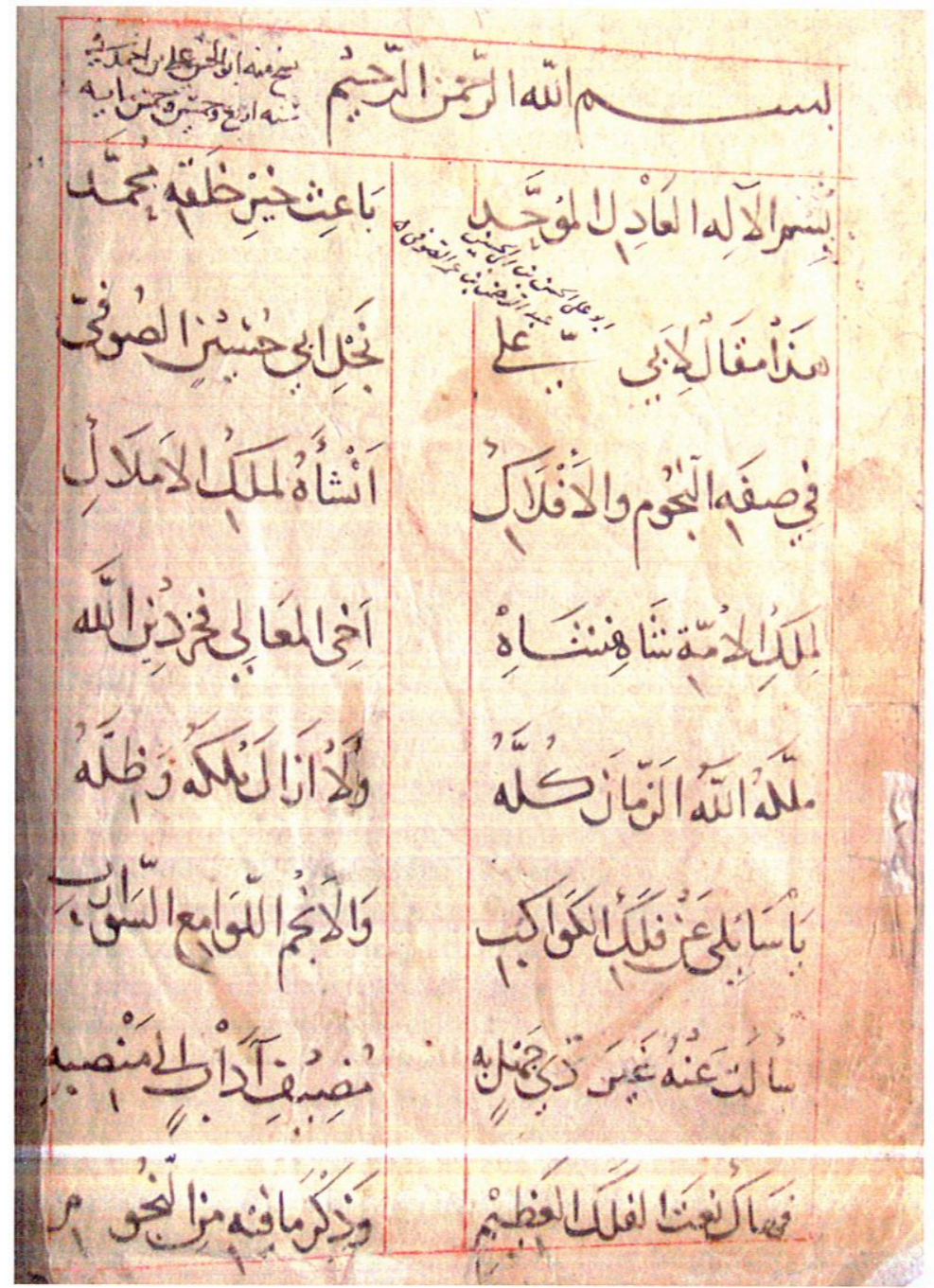

Fig. 2. Opening text: RAM Ibn al-Sufi, page 4. (Photo: Anna Contadini, courtesy of the Reza Abbasi Museum, Tehran)

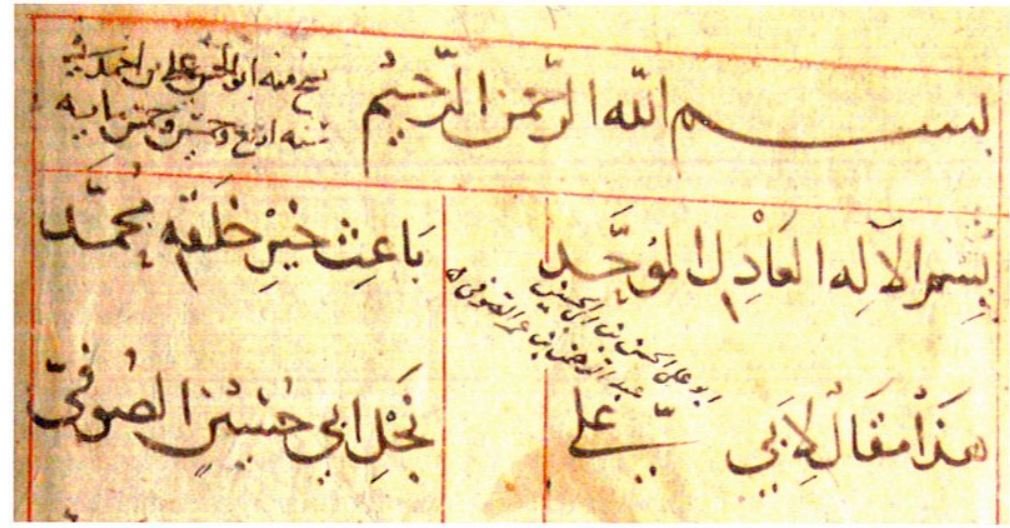

Fig. 3. Detail of the added inscription with the date 554 (1159). RAM Ibn al-Sufi, page 4. (Photo: Anna Contadini, courtesy of the Reza Abbasi Museum, Tehran) 
tions, the dimensions of the basmala cease to appear odd: there are many manuscripts in which it is not stretched to fill the line, and we need not assume that its length was determined by the need to accommodate the inscription that follows it, which seems all the more to be a subsequent interpolation.

The second reason for doubting the inscription concerns the script in which it is written. Close examination reveals that it is in a different hand from the main text, and furthermore that the ink used to write it is also different. ${ }^{6}$ This points strongly to its being a later addition and further reinforces the conclusion that it was not conceived as part of the original disposition of the page.

The third point of contention is the wording: nasakha minhu Abu 'l-Hasan 'Alī b. Ahmad fì sanat arba' wa-khamsin wa-khamsimi $a$. This, it is important to note at the outset, is not a standard copyist's formula, and, partly in consequence, its precise import is unclear. The particular difficulty concerns the inclusion of $\mathrm{min}$. Without it, the meaning would be "Abu 'l-Hasan 'Ali b. Ahmad copied it (nasakhahu) in 554"; but with it the sense shifts, and two possible interpretations might be proposed: either "In 554 Abu 'l-Hasan 'Ali b. Ahmad copied something from this manuscript," or "In 554 Abu 'l-Hasan 'Ali b. Ahmad made a copy of all or part of the same text."

Linguistically, considered purely as statements, these two alternatives seem equally plausible, the suffix pronoun presumably referring in the first case to (ha dha al-makhtüt or al-nass, and in the second to (hädhāa) alnass or al-maqāl. Where they crucially differ is in their temporal implications: according to the first, if a further copy was made in 554, the RAM manuscript itself must itself date from 554 or earlier, whereas according to the second, 554 refers to an act of copying from which one can infer nothing with regard to the date of the RAM manuscript. As for the reason behind this added comment, one might conjecture in the first case that Abu 'l-Hasan 'Ali b. Ahmad was sufficiently famous as a scholar or copyist for the mention of his name, right at the beginning of the text, to lend prestige to this manuscript and, by implication, validate it as a faithful copy of the original. Rather more prosaic, but at the same time more likely, is the supposition, relating to the second interpretation, that the inscription was added by a librarian or later owner who wished to cross-reference a different manuscript in the same collection, dated 554, that contained all or part of the same text.

\section{THE REZA ABBASI MUSEUM MANUSCRIPT}

M. 570 is of small format, measuring ca. $24 \mathrm{~cm}$ in height $x 16 \mathrm{~cm}$ in width. It has seventy-six pages (thirtyeight leaves, or forty including flyleaves), with fortyone constellation drawings and two full-page frontispieces. Page size is ca. $22.5 \times 15.5 \mathrm{~cm}$; the text block (framed) is about $18.5 \times 12 \mathrm{~cm}$; and the text has a maximum of eleven lines to the page, split into two columns measuring ca. 18.5-19 x $5.2 \mathrm{~cm}$. The binding is of blind-tooled brown leather, with a round medallion in the middle and small corner decorations contained within a geometric border. The margins of both binding and pages are damaged, and there are some repairs. The script is a neat, dark brown naskh. The manuscript is paginated in Arabic numbers on each folio side (for example, instead of $1 \mathrm{r}$ and $1 \mathrm{v}$ we have 1 and 2), so that the numbers go up to 76 . Titles and rubrics are in red ink.

On page 1 we find the title of the book, Risälal alSüfí fi 'l-kawākib, within a bracketed roundel (fig. 1). The title and roundel are in gold, and the roundel is framed by a blue line.

On page 4, after the two frontispieces, we find the beginning of the text (fig. 2), which opens with the basmala and, on the same line, the dated inscription. The text that follows is virtually identical with that of the 1954 Hyderabad edition, ${ }^{7}$ mentioning author and patron in lines $2-4$ :

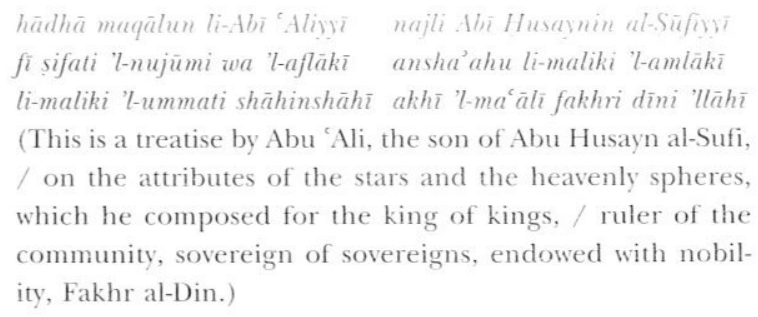

The full name of the great astronomer and author of the treatise to which the urjüza relates is Abu 'l-Husayn 'Abd al-Rahman b. 'Umar al-Sufi. Born in Rayy in 903, he died in Baghdad in 986, and it was during his time as tutor to the Buyid Sultan 'Adud al-Dawla Fana Khusraw (r. 949-83) that he wrote for him the Kitäb Suwar al-kawākib al-thābita, which dates from $965 .{ }^{8}$ As to the identity of the author of the urjüza, there has been some disagreement among scholars, despite the inference that Abu Ali najl (metri causa for "ibn") Abi Husayn al-Sufi was the astronomer's son. Brockelmann ${ }^{9}$ dismissed this identification, suggesting instead an Ibn 
al-Sufi who was a mathematician active in 1135-36 in the service of the Artuqid ruler of Hisn Kaifa, Qara Arslan (Fakhr al-Din, fl. 1143-44), with whom he equated the Fakhr al-Din mentioned in the poem. ${ }^{10}$ However, in the 1125 al-Sufi manuscript now in Qatar (see endnote 3 ), the text of the poem is headed by an inscription (folio 162r) stating that it was written by a son (walad) of al-Sufi, and later scholarship has preferred this identification. ${ }^{11}$ The colophon of the Bodleian library copy, dated 400 (1009), of the main astrological text by al-Sufi names al-Husayn b. 'Abd al-Rahman b. 'Umar b. Muhammad as the scribe of the manuscript, and this has been interpreted as the name of al-Sufi's son, ${ }^{12}$ while the present text includes a later diagonal inscription added above $l i-A b \bar{\imath}{ }^{c} A l \bar{\imath}$ (fig. 3) that gives a fuller version of the alleged author's name: Abu 'Ali al-Husayn b. Abi al-Husayn 'Abd alRahman b. 'Umar al-Sufi. ${ }^{13}$ The 1125 Qatar manuscript appears exceptional in having a prose introduction that mentions the father-son relationship; in other copies, the RAM manuscript included, the only evidence is that provided by the line citing Abu 'Ali najl al-Husayn al-Sufi. Unless it is considered an interpolation, however, this identification is difficult to ignore, especially as meter and rhyme offer a certain defense against tampering. ${ }^{14}$ Thus the son seems the most likely authorial candidate.

Regarding the patron, here again more than one candidate has been put forward, for in place of Qara Arslan, Aziz-zada suggests a double homage to Buyid amirs, the titlc shähinshäh being a reference to Fana Khusraw Abu Shuja 'Adud al-Dawla (the pupil and patron of the astronomer al-Sufi), and Fakhr Din Allah being his younger brother Fakhr al-Dawla Daylami. ${ }^{15}$ This appears ingenious but is unconvincing: the presence of ma'a $\bar{l} \bar{l}$ between $a k h$ and the following name severs the connection. In addition, it would be most unusual to combine references to two patrons, and it would be a curious poetic license that converts Fakhr al-Dawla into Fakhr al-Din. (Furthermore, if we are to have a Fakhr al-Dawla, there is yet another chronologically possible Buyid candidate, Fakhr alDawla 'Ali.) ${ }^{16}$

Inscriptions and seals testify that the manuscript was owned by various private individuals from the fourteenth through the nineteenth century. The oldest inscription, probably datable to the early fourteenth century, is found on the title page, page 1 (fig. 1). In Arabic, the substantive part reads as follows:

min kutub al-'abd al-da'îf al-nahîf al-rājī ilā rahmat almalik al-majïd /
Muhammad b. Yahyà b. Fadlallāh al-khatīb al-mánüf biKhwourd(?) al-Mu'arrif

(One of the books of the feeble and wretched servant who hopes for the mercy of his glorious Lord, / Muhammad b. Yahya b. Fadlallah, the preacher known as Khwurd(?) al-Mu'arrif.

Two other inscriptions, in Persian, are found at the bottom of the same page, in $t a^{\prime} l \bar{q} q$ script. The owners belonged to the same family, and their inscriptions are possibly to be dated, according to Aziz-zada, to the early fifteenth century. ${ }^{17}$ There are also three seal impressions-two at the bottom, not completely legible, as the margin of the page is damaged, and another higher up on the left-hand side of the page. It is possible to establish that they contain ownership inscriptions, although unfortunately without dates. Two more such inscriptions, one a seal impression and the other written in shikasta, are found on the last page of the manuscript, page 76 , and possibly belong to the late Safavid period (fig. 27).

As a stamped inscription on the flyleaf reveals, in the nineteenth century the manuscript was in the hands of Fakhr al-Din Nasiri Amini, a collector and dealer of manuscripts, and was no. 156 in his library. After that, it passed to the Mahboubian family, also collectors and dealers of manuscripts, and the urjüza is in fact mentioned in the catalogue produced by Mehdi Mahboubian in 1970. Mahboubian sold many items to Queen Farah Diba for her roval collection, including, we may safely assume, this manuscript, as the Queen eventually donated her collection of ancient and Islamic Iranian art to be part of the Reza Abbasi Museum, established in 1976.

The manuscript has thus passed through many hands before arriving at the museum, and the plausibility of the inscription with the date having been added as part of a library check is reinforced by the fact that there was obviously great interest in this classical text throughout the centuries, as demonstrated also by the existence of a Qajar copy of the RAM manuscript. It is also interesting, when considering the inscription, to note that the manuscript has been in other ways "tampered with" on different occasions. For example, some diacritical marks have been added later, in blacker ink, and some of the letters have been re-outlined: one instance of this is the first $h \bar{a}^{2}$ of shähinshāh, in the shape of an 8 , on page 4 (fig. 2). In the margins there is a Persian commentary, undated but certainly added later-sometime in the sixteenth or 
seventeenth century (or possibly later), judging from the nasta'liq script. In addition, as stated above, the thin red lines that frame the text are not original; they were most probably added when the Persian commentary was written in the margins, as the red ink in which they are written is the same as that used for the rubrics in the commentary but different from that of the rubrics of the main text. Further confirmation is provided by the fact that in certain places they accommodate the Persian commentary, e.g., on pages 6, 16, 23 (fig. 14), and 48 (fig. 16), where they are either drawn at an angle or interrupted. In addition, as also mentioned, the two internal middle lines on page 4 are neatly interrupted to accommodate the later, diagonal inscription that gives the full name of the author (fig. 3). Furthermore, the letters alongside various stars and the numbers that appear within the constellation titles are also later additions, again in the same red ink as the frames of the text. The catchwords at the bottom left corner of the pages were also added later, as they are in a darker ink and a different hand.

In one instance the painter has made a mistake in the iconography of the constellations. The title of Hercules, al-Jâthi 'alā rukbatayhi, which appears on page 19, is followed (on the other side of the folio, page 20) by a picture of Orion, while the picture of Hercules appears on page 60, preceded, on 59, by Orion's titles, al-Jabbār/al-Jawzä'. Elsewhere, incorrect sequences result from the order of the folios having been disturbed. For example. a picture and the end of the text (two lines) of al-Sulyang (Lya) appears on page 22, while the preceding text of Lvra, together with the title, is to be found on page 61. Finally, at some stage after the catchwords were added, a number of folios were detached from the manuscript. The section devoted to Perseus, with one miniature, should come between pages 24 and 25 as they are now numbered; missing between pages 56 and 57 are the constellations Capricorn and Aquarius and the beginning of Pisces (but not its picture, so just two images are lacking from this group); and between pages 63 and 64 should appear Canis Major and Canis Minor, together with their pictures. In all, then, five pictures are missing.

\section{THE QAJAR COPY}

As reported by Aziz-zada, a Qajar copy, dated 1312 (1894), of the RAM Ibn al-Sufi is found in the Majlis
Library in Tehran. ${ }^{18}$ The manuscript now in the RAM may have appealed to a Qajar patron or copvist because it included illustrations of all the constellations, which is not often the case. The copy follows the text and the iconography of these illustrations very closely and reflects the state of the original manuscript prior to the loss of some of its folios and the disruption of its order. For example, the whole section of Lyra appears in correct sequence (on pages 12 and 13), while of the five missing constellation drawings, Perseus (Birshäwush) is found in the Qajar copy on page 14, where it is represented with a rather dramatic picture (fig. 10 left), and Aquarius occurs on page 27 (fig. 11) - evidence that the folios containing these two miniatures were taken out of the manuscript after the copy was executed. The other three miniatures, however, are missing from the copy, probably indicating that they were detached from the manuscript at some earlier stage. To judge by the example of Hercules and Orion, the illustrations of which are now correctly placed, the Qajar copyist had sufficient knowledge of both text and iconography to rectify such blunders.

A more intriguing case is presented by the illustration of Andromeda. Apart from the few cases, like Cygnus and Cancer, in which constellations are represented as if seen from above and therefore do not have a "direction," the copies follow the original drawings in facing left. But in the depiction of Andromeda (fig. 19) the Qajar artist has reversed his drawing. so that she now has the fish across her left arm and not, as in the R.MI manuscript-in which the fish is slightly effaced-across her right (fig. 20). In the absence of outline marks, this cannot be explained simply by the reversal of a model, and although an explanation is hard to come by, it may be hypothesized that it has something to do with the fact that in the al-Sufi treatises the constellations are usually represented in mirror-image pairs. ${ }^{19}$ The Qajar copvist, being familiar with this tradition, may in this instance have simply preferred the alternative view. In any case, the copyist appears to have had knowledge of both text and images, and this copy is valuable testimony to a continuing interest in classical scientific knowledge in the Qajar period.

The two manuscripts have the same number of folios (38) and an almost identical format (RAM ca. $24 \times 16 \mathrm{~cm}$; Majlis $25 \times 16.5 \mathrm{~cm})$; the drawings are also very similar in size (for example, Ursa Minor measures $6 \times 9.5 \mathrm{~cm}$ in the RAM original and $5.5 \times 8.5$ $\mathrm{cm}$ in the Majlis copy). In the RAM manuscript the 
constellation drawings have been drawn in a thin red line before being outlined in black ink, a feature common to early-thirteenth-century manuscripts, but such preliminary red outlines are not present in the Qajar copy. In fact, the Qajar illustrator seems to have made his copies freehand rather than by standard means of mechanical transfer: in the Reza Abbasi Museum manuscript there is no trace of pricking or of the indentations left on the page by a sharp tracing tool such as are so often found around the drawings of al-Sufi manuscripts. The Qajar copy likewise shows no sign of the outline of the drawings having being marked on the page prior to execution.

Unfortunately, there are no frontispieces in the Qajar copy, and the manuscript is also unfinished to the extent that the spaces for certain titles, including the one at the top of the first page, have been left blank.

\section{THE CONNECTIONS WITH}

\section{EARLY-THIRTEENTH-CENTURY ARAB PAINTING}

The frontispieces of the RAM manuscript, on pages 2 and 3 (fig. 4), each portray a figure sitting on a throne; the one on the right holds an astrolabe and the other a book. The left-hand figure is white-bearded and wears a turban, while the dark-bearded one opposite wears what looks like a hairband and seems to sport an earring. The rest of his costume is similar to that of his companion on the left. however. and both have gold haloes around their heads. The two figures face each other, the one on the left in profile and the other in three-quarter view.

About these figures, Aziz-zada has advanced two hypotheses. According to one, the figure on the right could be the ancient authority Ptolemy, whose star table in his Almagest is the basis for al-Sufi's treatise, and the white-bearded figure on the left the author of the book, reading it to Ptolemy. ${ }^{20}$ But although this conforms to the common representation of preIslamic sages without turbans, it runs counter to the usual hierarchy of authority coded by beard color. For example, although arabicized and wearing a turban, Aristotle is represented in an al-Mubashshir Mukhtār alhikam wa-mahāsin al-kalim ${ }^{21}$ as a white-bearded ancient authority holding an astrolabe in front of a crowd of students with books (fig. 8). Moreover, unless the author of a work derived from al-Sufi's treatise could reasonably be expected to seek the approval of Ptol- emy rather than al-Sufi himself, the reference would have to be not to the author of the present text, but to the tenth-century astronomer. Similarly, if it were proposed that the figures represented are al-Sufi, who would have to be the older figure on the left, and his son, the likely author of the urjüza, we would have to accept a flouting of convention whereby the reader of the book is not the author but the font of wisdom imparting knowledge to the (presumably prospective) author.

Aziz-zada's other hypothesis proposes that the figure on the right is the patron of al-Sufi, 'Adud al-Dawla (the earring would then prefigure later Persian representations of princes), and the figure on the left alSufi himself, reading his text to his prince. ${ }^{22}$ This interpretation accords partially with Aziz-zada's proposal that the dedicatory inscription in the text could be a double homage to Buvid amirs. In both cases the representation is anachronistic, but for this there is the possible defense that it is a deliberate attempt to give prestige to the book by affiliating it with illustrious personalities. But one could equally well propose a non-anachronistic alternative, namely, that the figure on the left is the author of the urjuza, and that on the right his patron, the Fakhr al-Din referred to in the text. Indeed, while the figure on the left is definitely an old sage absorbed in his reading of a book, the one on the right conveys a slightly irreverent attitude: he sprawls and looks curiously at the astrolabe he is holding. Princely status is suggested, again, by his earring: and he has a golden bowl of fruit at his feet, which also seems to be associated with authority, whether intellectual or political. For example, the 1244 Dioscorides Khawäss al-ashjär (The Properties of Plants) in Bologna has a full-page miniature of Dioscorides seated on a throne in the center, picking a fruit from a gold bowl held by Aristotle, on the left; and in one of the $\mathrm{Na}^{\mathrm{c}} \mathrm{t}$ frontispieces the figure identifiable as the possible patron of the text is again seated on a throne and has a fruit-filled golden bowl at his feet. ${ }^{23}$

However, it is also perfectly possible to read the frontispieces as embodying a general iconographic theme, found in many scientific manuscripts, of the "transmission of knowledge." According to this view the figures do not need to be identified with any particular personage; they serve, rather, as a reminder of the general concept of the importance of knowledge, of how it is imparted from teacher to student, and, perhaps, of the vital role of the book itself as a record of the successful completion of this task. 


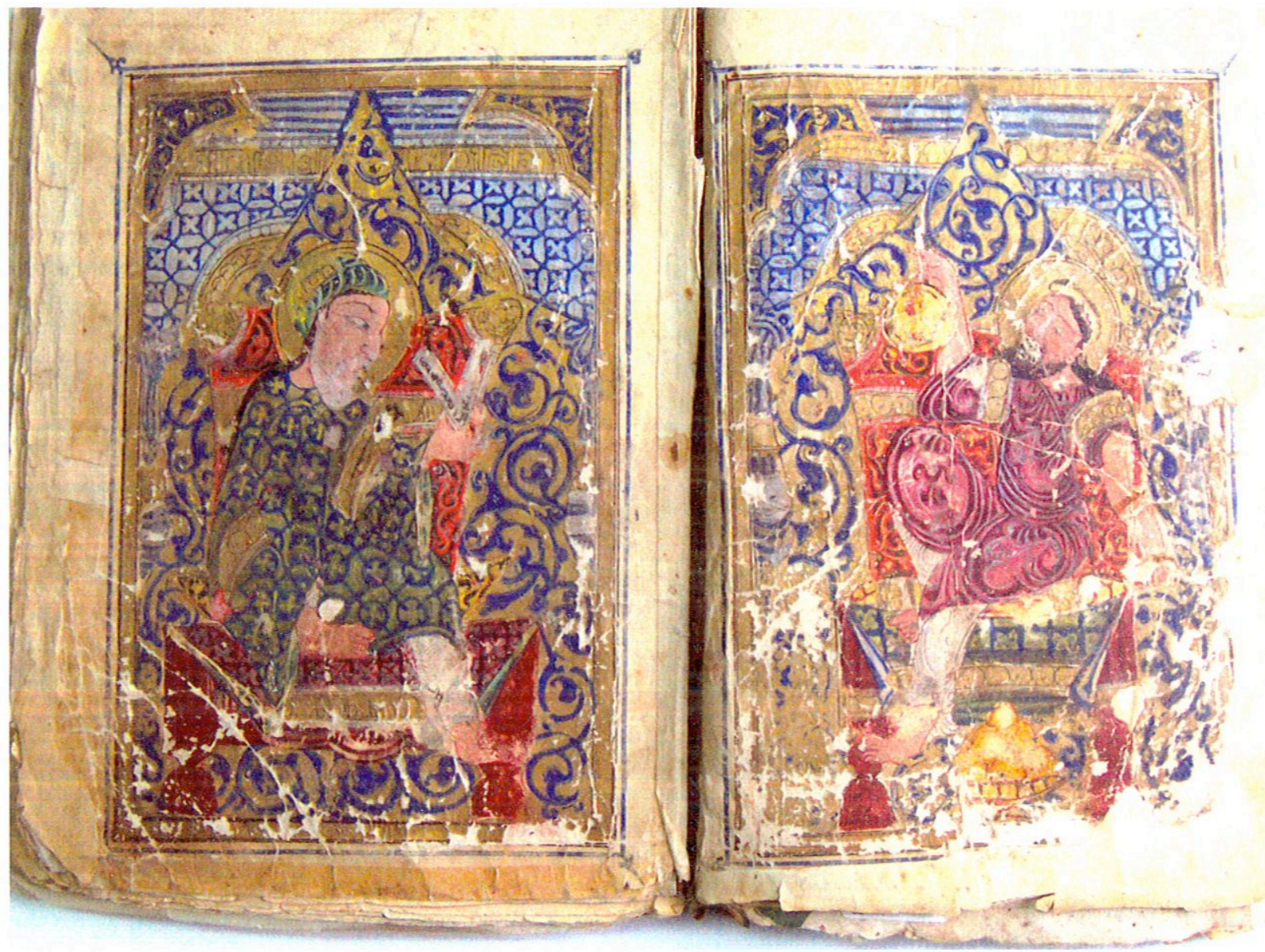

Fig. 4. Frontispieces. RAM Ibn al-Sufi, pages 2-3. (Photo: Anna Contadini, courtesy of the Reza Abbasi Museum, Tehran)

In iconographical terms, the two frontispieces are very similar to two of the four in the $N a^{\prime} t$, those on folios $3 \mathrm{v}$ and $4 \mathrm{r}$ (figs. $9 \mathrm{a}$ and $9 \mathrm{~b}$ ), which also depict two enthroned figures, the one on the left turned slightly towards the other, who, in frontal position, represents royal authority. There are striking similarities between the thrones, which have high, decorated backs with slightly flared shoulders, thickly molded legs, and seats covered by carpets with inward-folded corners, on top of which are cushions. The RAM frontispieces each have as background a gold canopy patterned with blue vine scrolls, which descends from the ceiling and widens to cover the back of the throne. Although the two aforementioned frontispieces in the $N a^{c} t$ (folios $3 \mathrm{v}$ and $4 \mathrm{r}$ ) have solid gold backgrounds, the other two (those on folios $2 \mathrm{v}$ and $3 \mathrm{r}$ ) have gold backgrounds covered by very similar vine scrolls. The arches at the top corners are also similar architectonic references, while the textile designs in the Tehran manuscripts-for example, the checkered pattern of the two throne carpets, each with a row of gold roundels near the border-are practically identical to those in the $N a^{c} t$ frontispieces. Furthermore, the clothing type-long tunics with white, baggy trousers underneath-is identical in the two manuscripts, as is the tunic decoration and rendering of folds: in these details one may compare the RAM figures not only to two of the $\mathrm{Na}$ 't frontispieces already mentioned (folios $3 \mathrm{v}$ and $4 \mathrm{r}$ ), but also to the figures on folios $101 \mathrm{v}$ and $96 \mathrm{r}$ in the $\mathrm{Na}^{\mathrm{c}} \mathrm{t}$ (figs. 5, 6). In addition, the pseudo-calligraphic tiraz bands represented on folio $101 \mathrm{v}$ are identical with those of various constellation figures in the urjūza, 


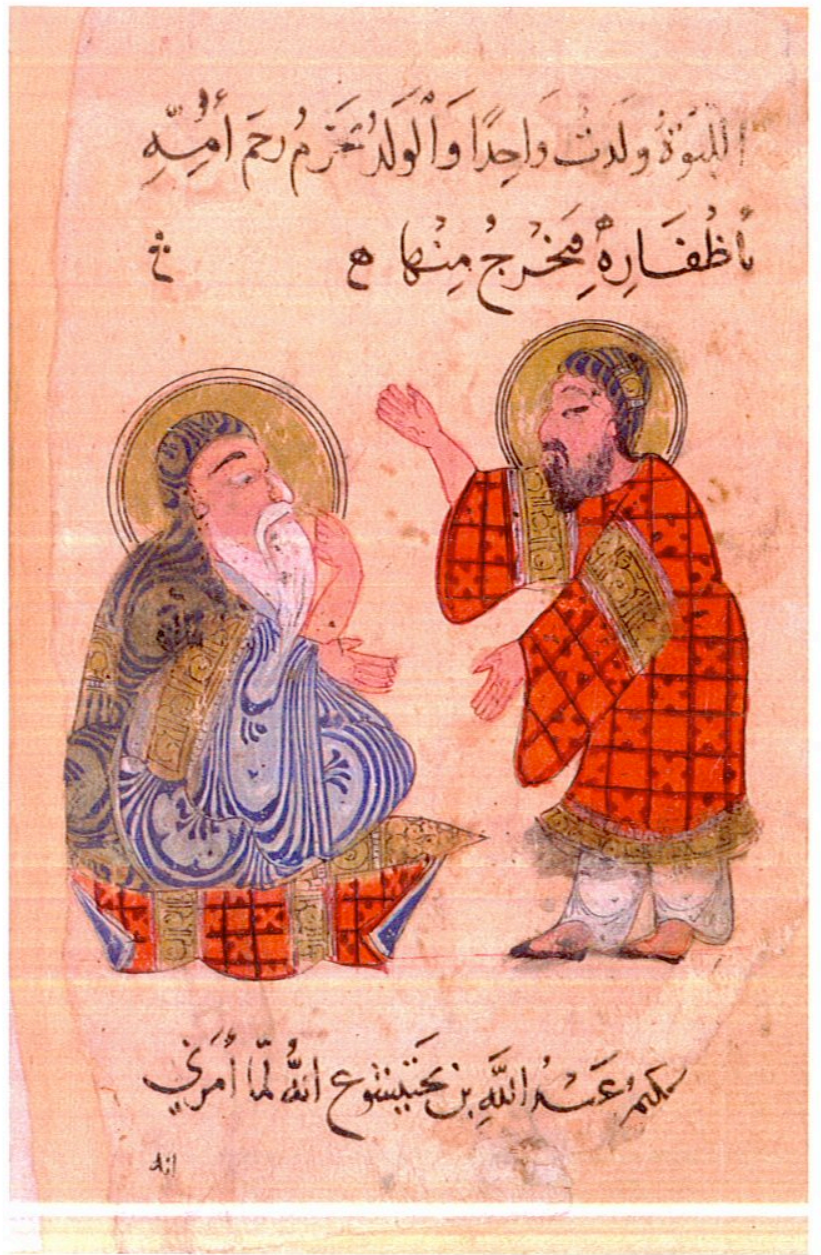

Fig. 5. Ibn Bakhtishu' and a pupil. From an Ibn Bakhtishu' Kitāb Na't al-hayawān, ca. 1220-25, North Jazira (?). London, British Library, Or. 2784, folio 101v. (Photo $\odot$ the British Library)

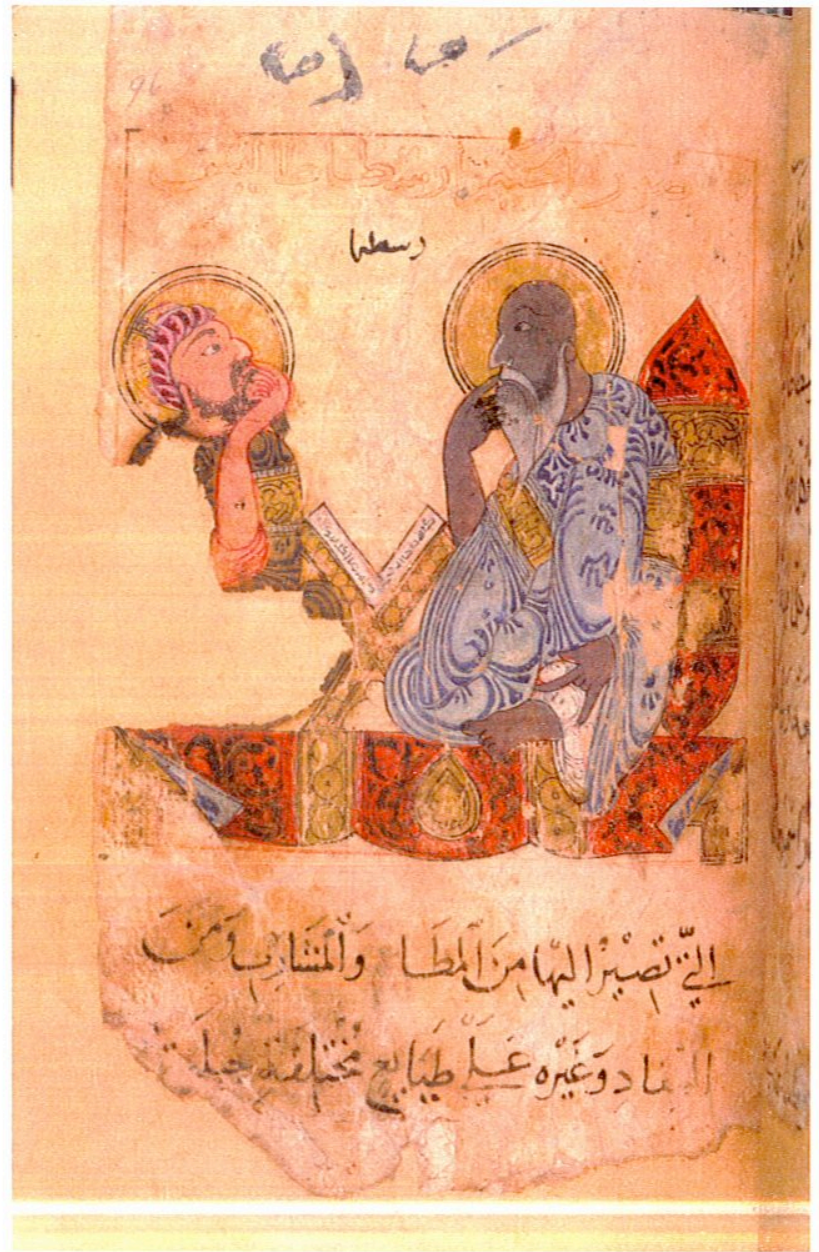

Fig. 6. Aristotle and a pupil. British Library $N a^{\prime} t$, folio $96 \mathrm{r}$. (Photo () the British Library)

to the constellation Leo on page 49 (fig. 16) and, for the face, Delphinus on page 32 (fig. 18) in the urjüza. In general, the animals' bodies are treated in a very similar manner: they are rather large and fleshy, with curved lines to mark the folds of the skin, as in the constellations of Ursa Minor on page 5 (fig. 12) and the bear in the $\mathrm{Na}^{\mathrm{c}} \mathrm{t}$ on folio $174 \mathrm{v}$ (fig. 13); Centaurus with Lupus on page 72 (fig. 22) and the onager on folio 15lv (fig. 23); Aries on page 41 and the ram on folio 111v; Cygnus on page 23 (fig. 14) and one of the domestic pigeons, second from the right in the upper row on folio 14r (fig. 15); Pisces on page 57 (fig. 24 left) and the mullet on folio 74v (fig. 25); 


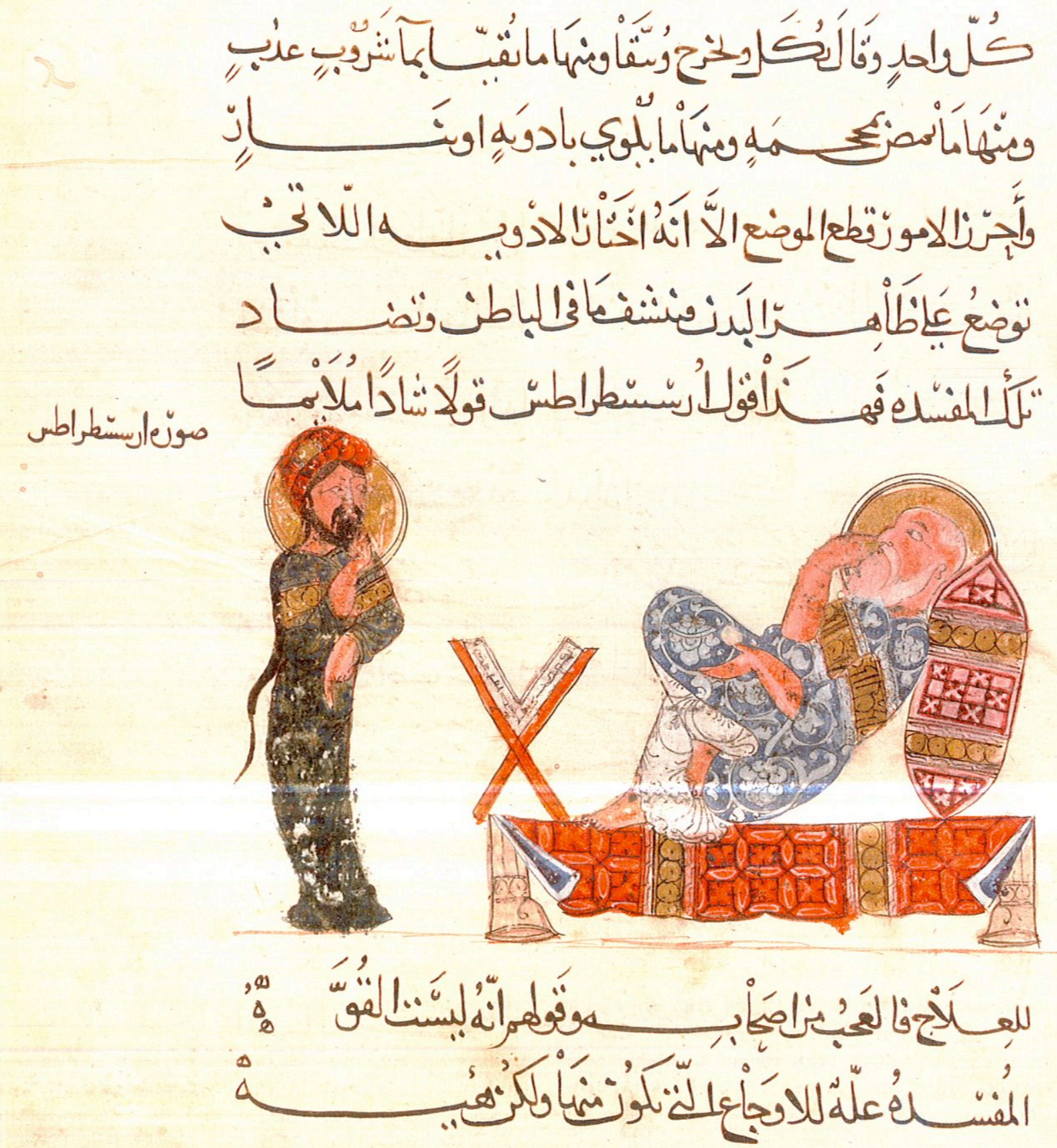

Fig. 7. Erasistratos and a pupil. From a Dioscorides Khawāss al-ashjār, dated 621 (1224), North Jazira(?). Washington, Freer Gallery of Art, F1947.5. (Photo: courtesy of the Freer Gallery of Art, Smithsonian Institution, Washington, DC) 


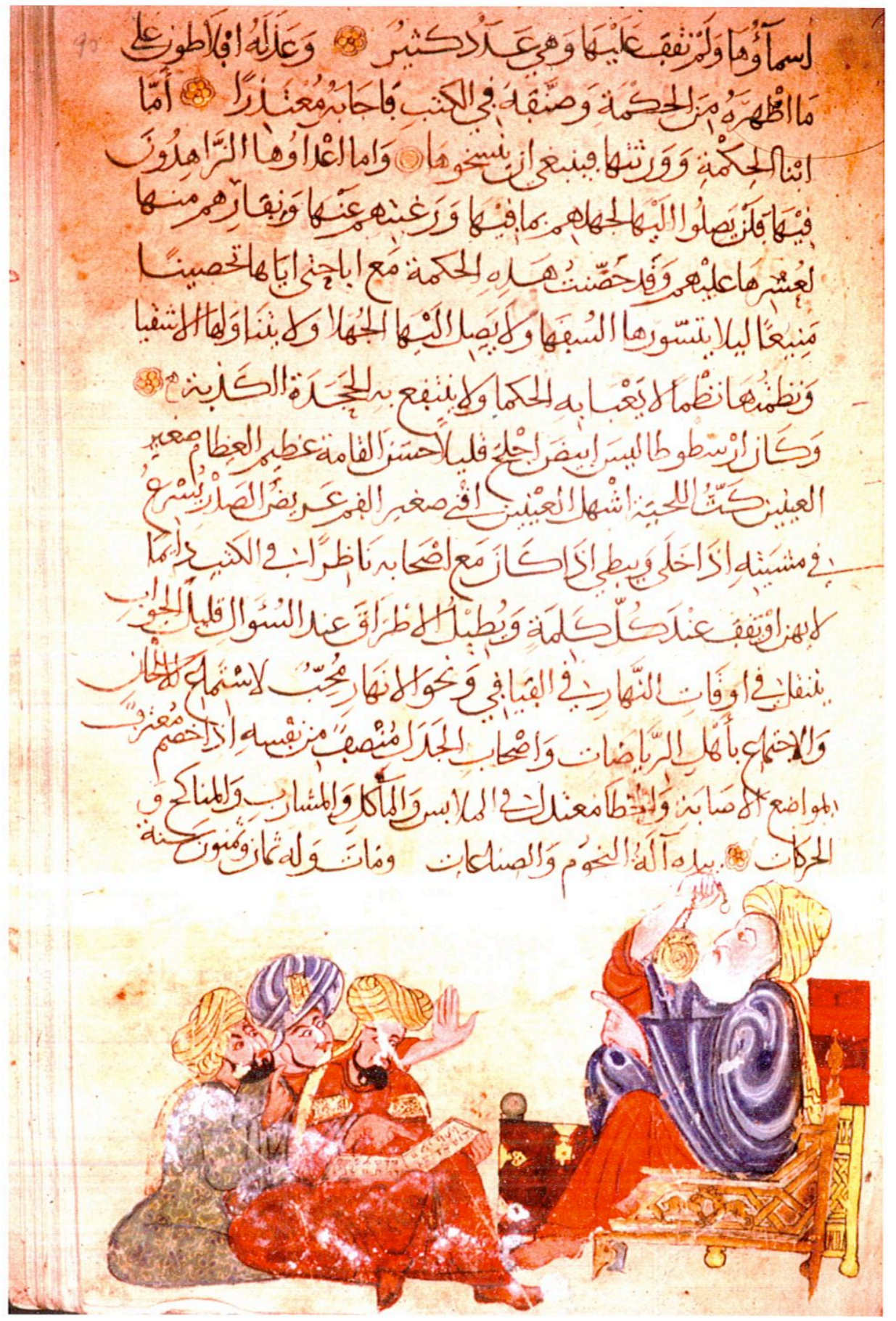

Fig. 8. Aristotle, holding an astrolabe, and students. From an al-Mubashshir, Mukhtār al-hikam wa-mahāsin al-kalim, Syria (?), early thirteenth century. Istanbul, Topkapı Sarayı Library, Ahmet III, 3206, folio 90r. (Photo: Anna Contadini, courtesy of the Topkapı Sarayı Library, Istanbul) 


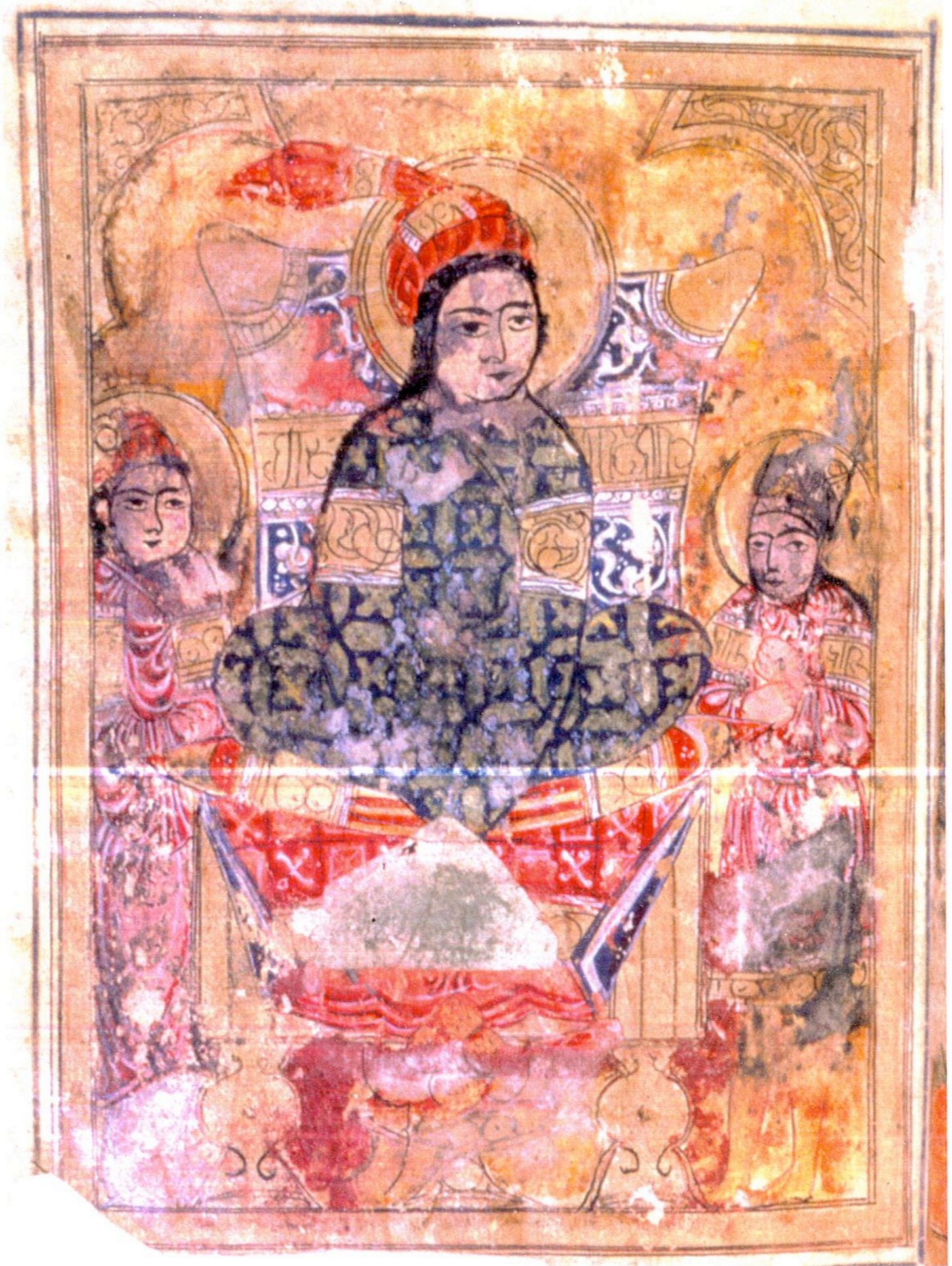

Figs. 9a (right) and 9b (left). Double-page frontispiece from the British Library $N a^{c} t$, folios $3 \mathrm{v}$ and $4 \mathrm{r}$. (Photo (c) the British Library) 


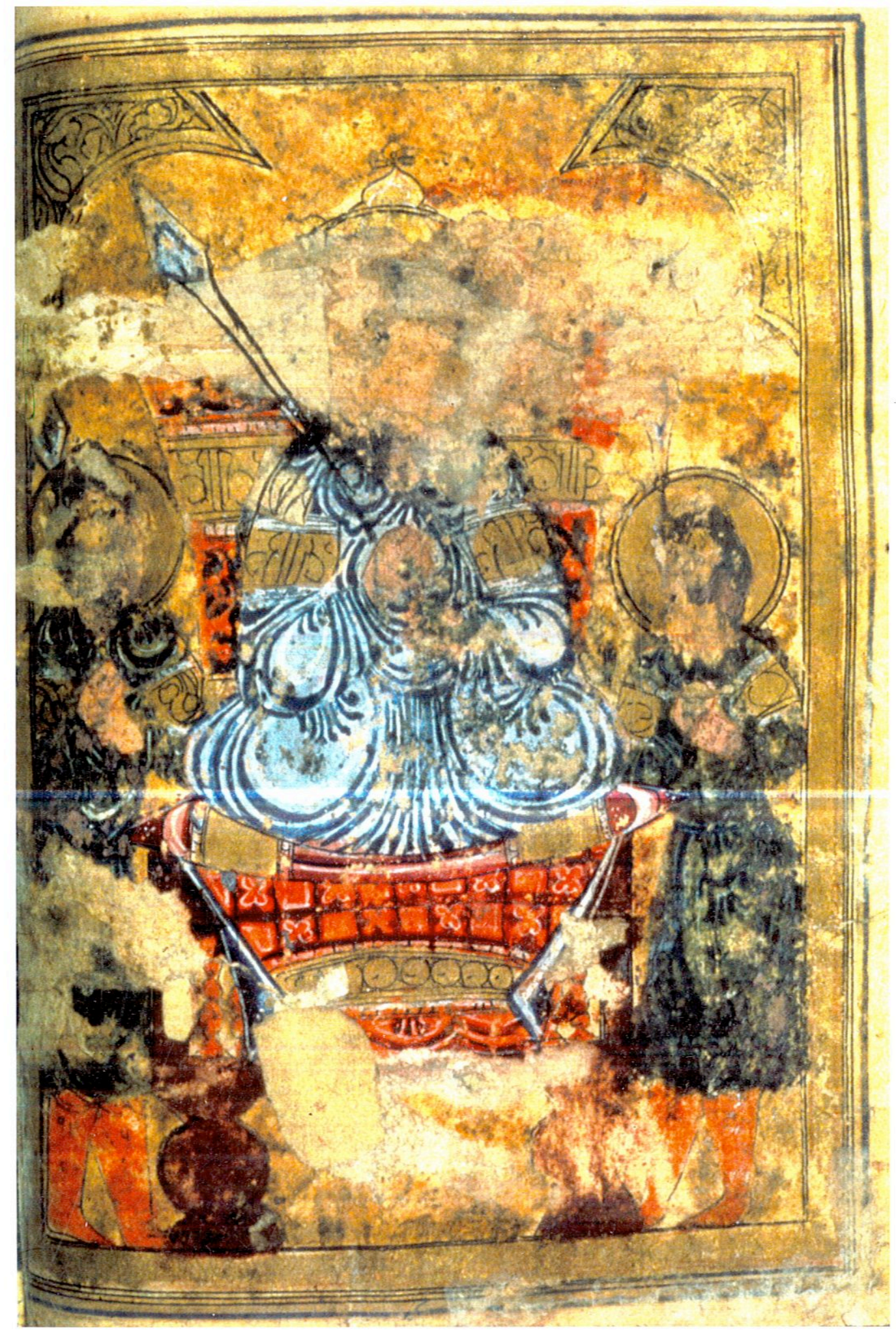




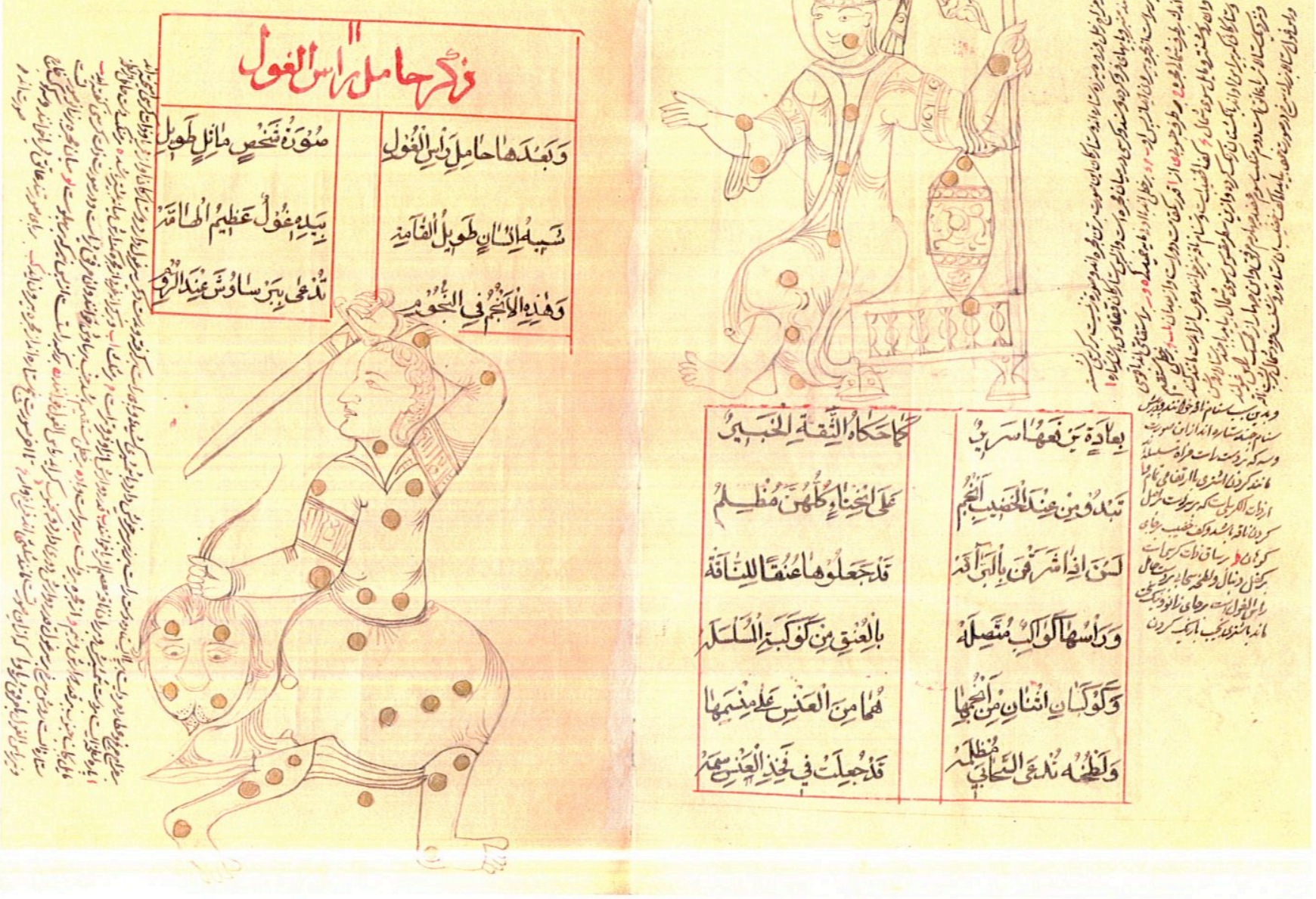

Fig. 10. Cassiopeia (right) and Perseus (left). From a Qajar copy of the RAM Ibn al-Sufi, dated 1312 (1894). Tehran, Majlis Library, no. 5099, page 14. (Photo: courtesy of the Majlis Library, Tehran)

and the wing of Pegasus on page 36 (fig. 20 right) and that of the unicorn on folio $197 \mathrm{v}$ (fig. 21).

Another striking feature that relates the urjüza drawings to thirteenth-century manuscripts is the alreadymentioned red outlines of the constellations, which have been drawn over in black ink. This is typical of early-thirteenth-century Arab painting, but less so of al-Sufi manuscripts (even if they belong to the thirteenth century), which more often have incised outlines, a feature absent from the RAM manuscript (and, incidentally, from the Majlis Library copy).

These close resemblances suggest, if not that the same artist worked on both the RAM Ibn al-Sufi and the $N a^{c} t$, then that the two manuscripts were illustrated by artists in a master-pupil relationship, or working in the same atelier, or both. Also consonant with such a conclusion is the similarity between the script of the RAM manuscript and that of the $\mathrm{Na}^{c} t$. Unfortunately, the delineation of a historical style-map of naskh, especially of the early periods, ${ }^{24}$ still lies in the future. We lack adequate criteria for situating a manuscript in time and place with any accuracy on the basis of its script; indeed, we even lack a sufficiently objective conventional vocabulary to define script features for comparative purposes. But despite this situation, we can still reasonably claim a broad family resemblance among the scripts of the various manuscripts of this group, and especially strong similarities between these two manuscripts in particular. 


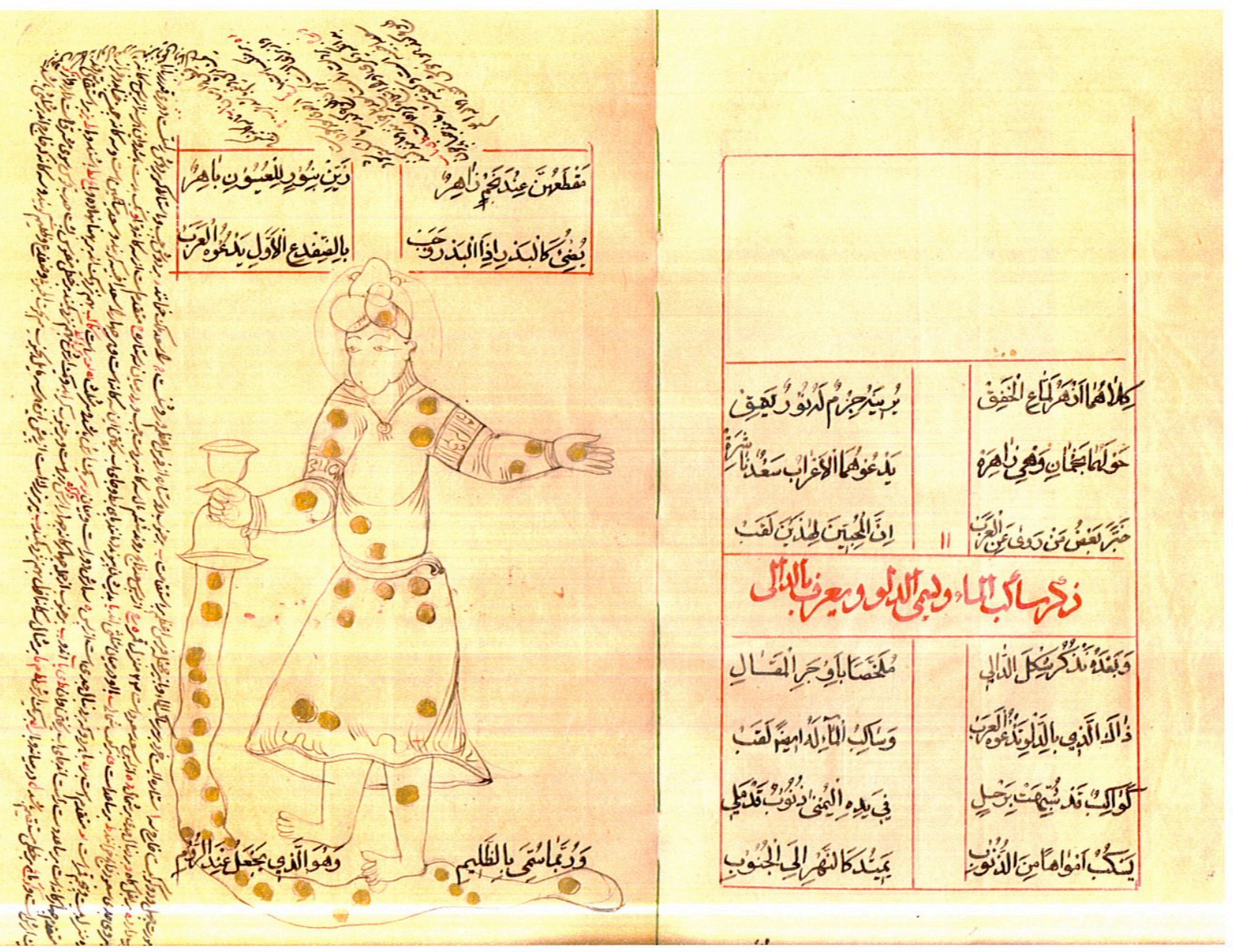

Fig. 11. Aquarius. Majlis Library Qajar copy, page 27. (Photo: courtesy of the Majlis Library, Tehran)

Because of these various parallels the conclusion is virtually inescapable that the RAM Ibn al-Sufi forms part of a strongly profiled group of early-thirteenthcentury manuscripts, and if, in the light of the dated inscription, further argument is needed, one need only point to the absence of such parallels with the surviving illustrated manuscripts of the twelfth century, including al-Sufi manuscripts. Those that were made close to 1159, whether from an Artuqid, Zangid, Abbasid, or Fatimid environment, all exhibit a different style of depicting human figures, and the line drawings in the al-Sufi and urjüza manuscripts from this period also differ in style from those in the RAM urjūza. ${ }^{25}$

Accepting the RAM manuscript as a further addi- tion to the thirteenth-century group, we can logically assign it a date close to that of the $\mathrm{Na}^{\mathrm{c}} \mathrm{t}$. On the basis of stylistic similarities with other dated manuscripts, in particular the above-mentioned 1224 Dioscorides (fig. 7) ${ }^{26}$ and Christian Syriac manuscripts-especially the 1220 Gospel book in the Vatican Library, produced in the monastery of Mar Mattai, ${ }^{27}$ and the 1216-20 Gospel book in the British Library, most probably also produced in Mar Mattai ${ }^{28}$ — the $\mathrm{Na}$ 't can be confidently assigned to around 1220--25. ${ }^{29}$ Given the extremely strong iconographical and stylistic similarities between it and the RAM manuscript, it is logical to suppose that the latter, too, was produced at that time.

The other members of the group consist of two 


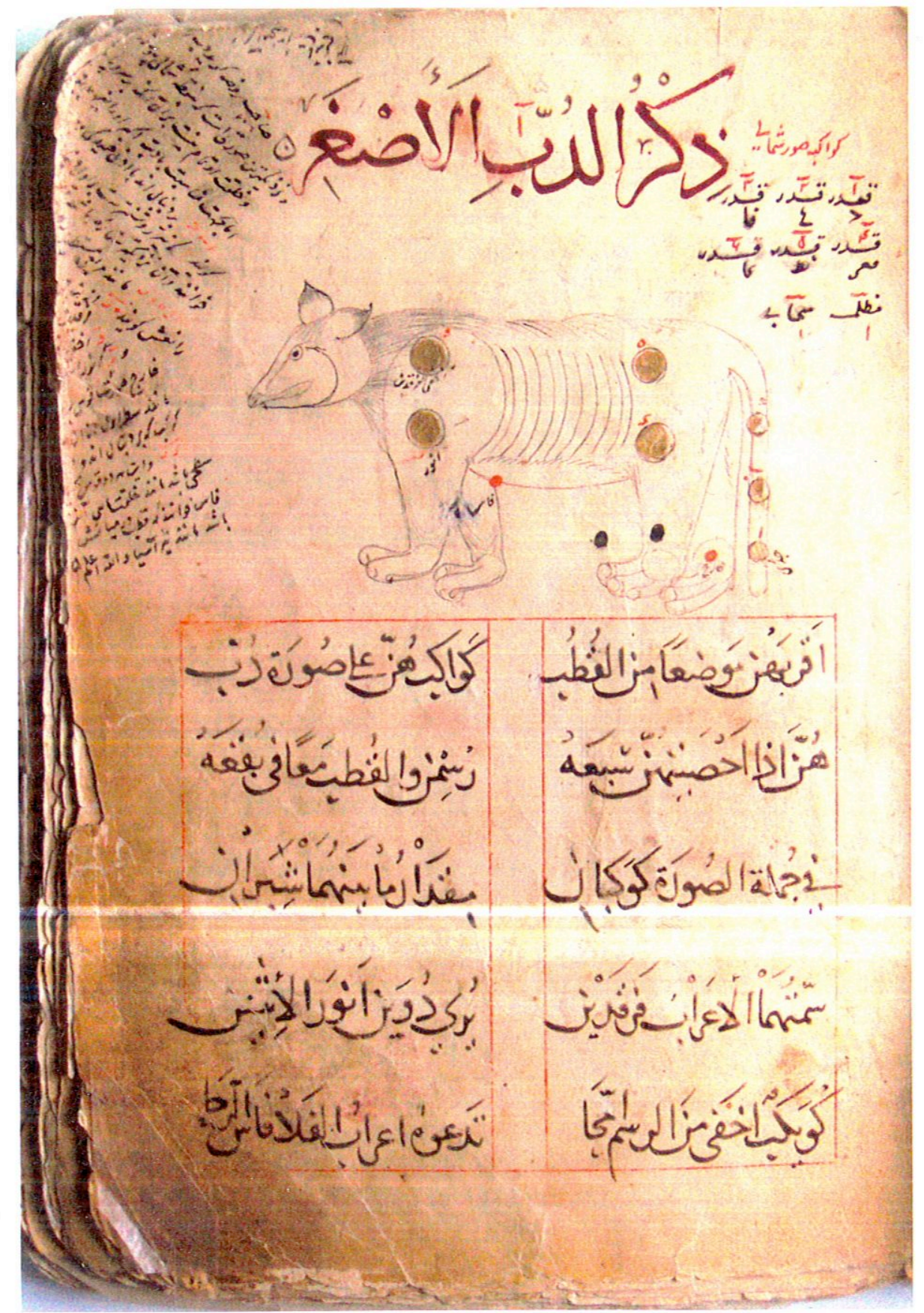

Fig. 12. Ursa Minor. RAM Ibn al-Sufi, page 5. (Photo: Anna Contadini, courtesy of the Reza Abbasi Museum, Tehran) 


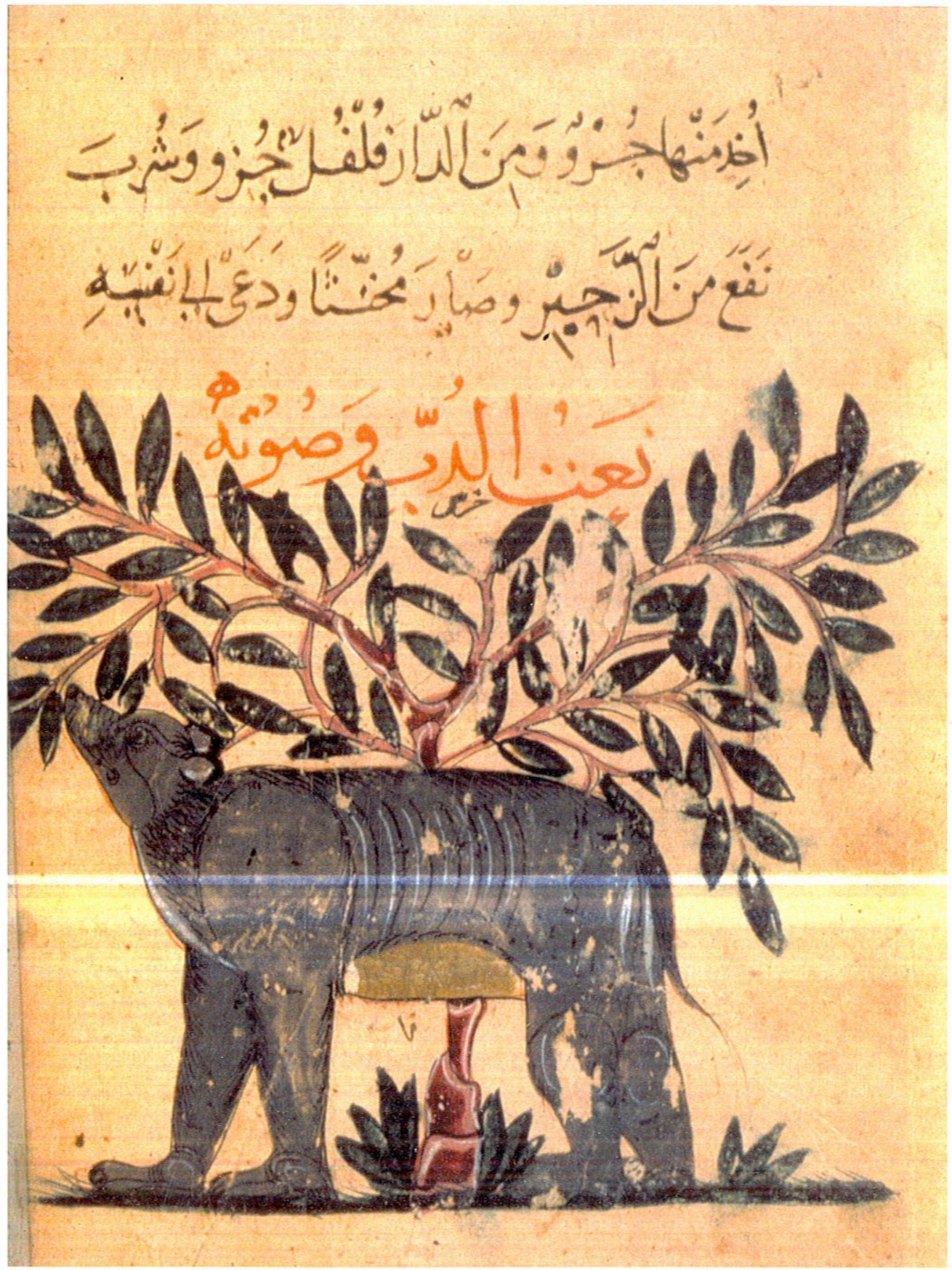

Fig. 13. Bear. British Library Na't, folio $174 \mathrm{v}$. (Photo $(\odot)$ the British Library) 


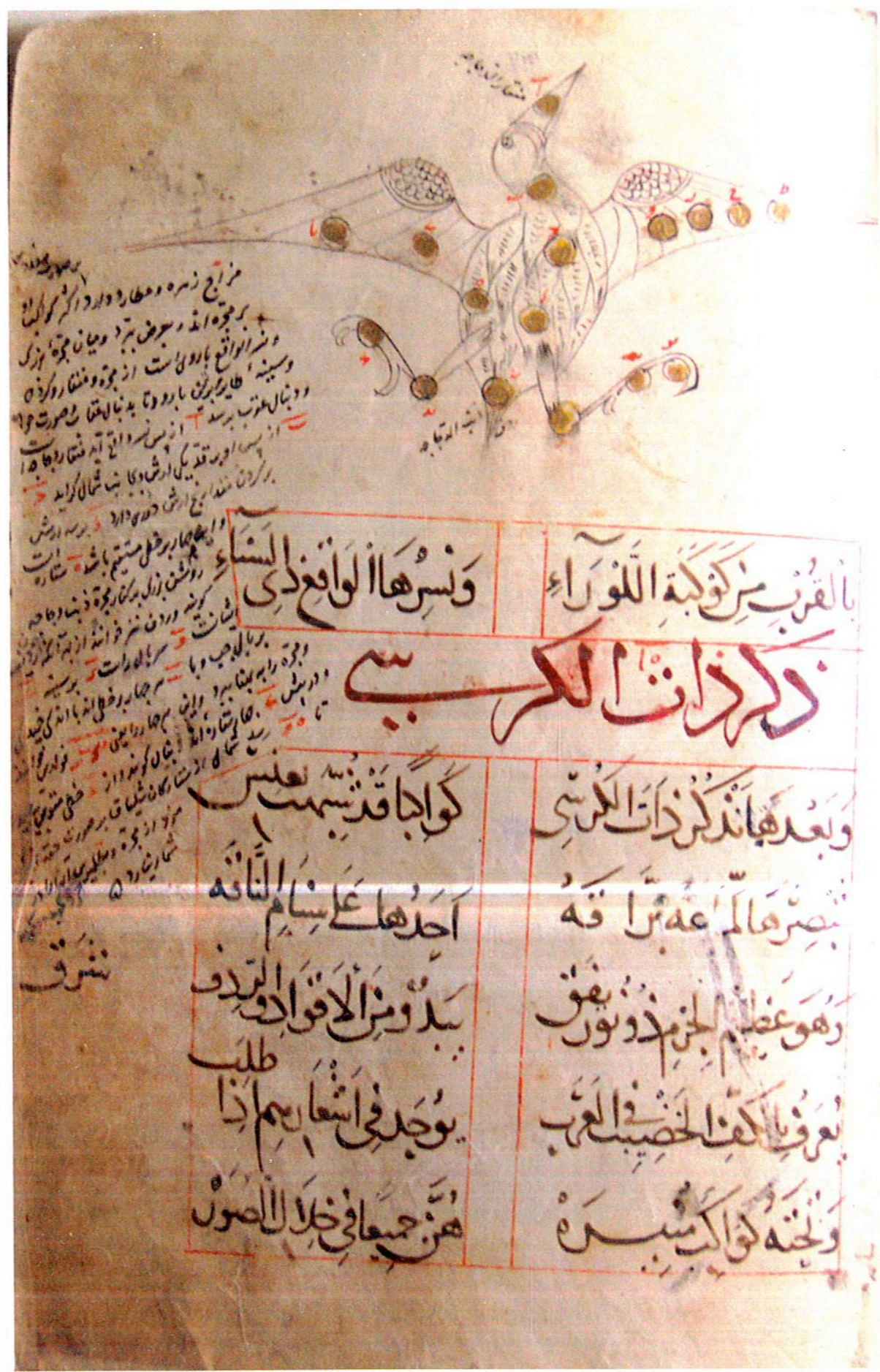

Fig. 14. Cygnus. RAM Ibn al-Sufi, page 23. (Photo: Anna Contadini, courtesy of the Reza Abbasi Museum, Tehran) 


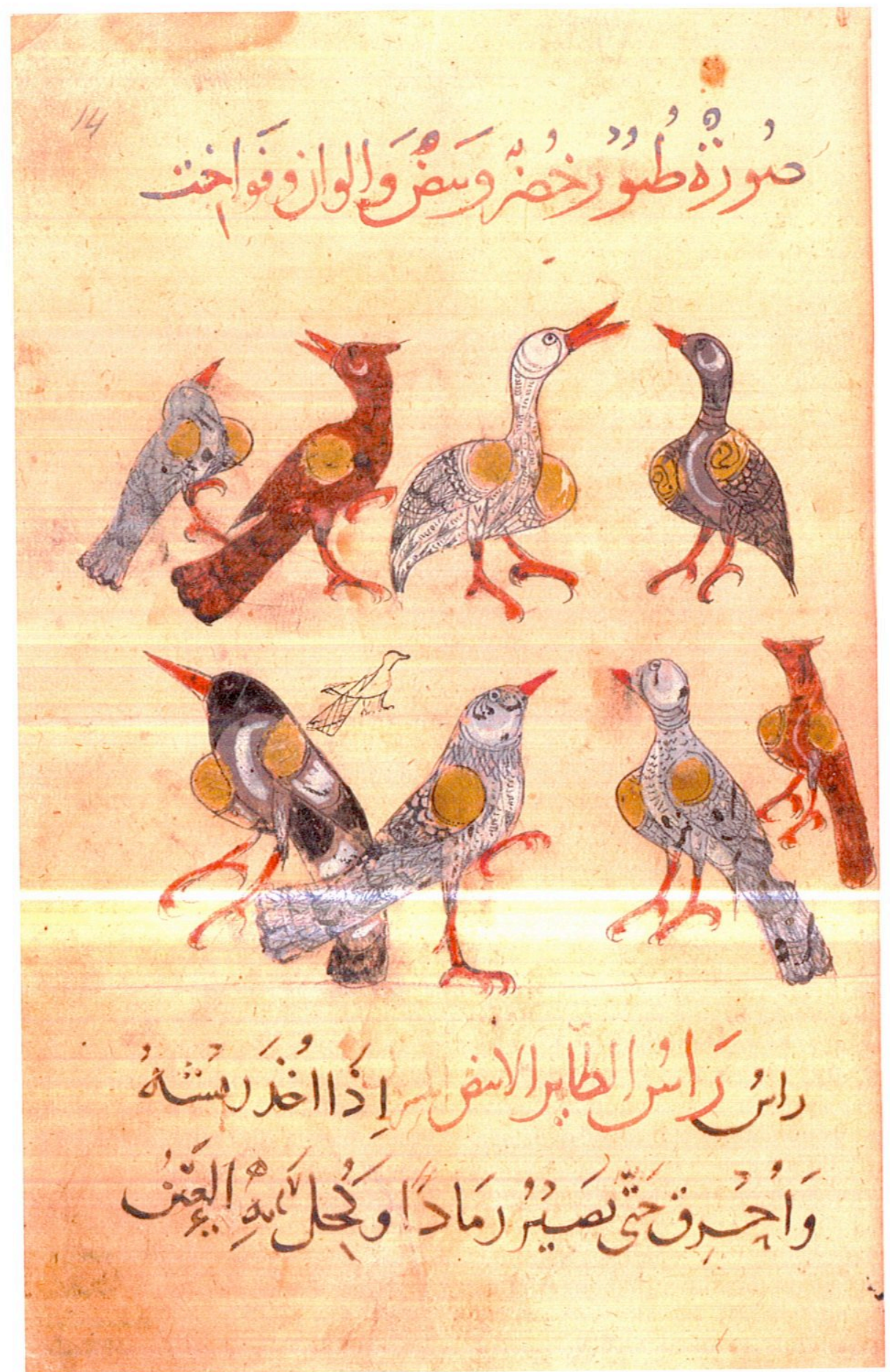

Fig. 15. Domestic pigeons. British Library Nact, folio 14r. (Photo @ the British Library) 


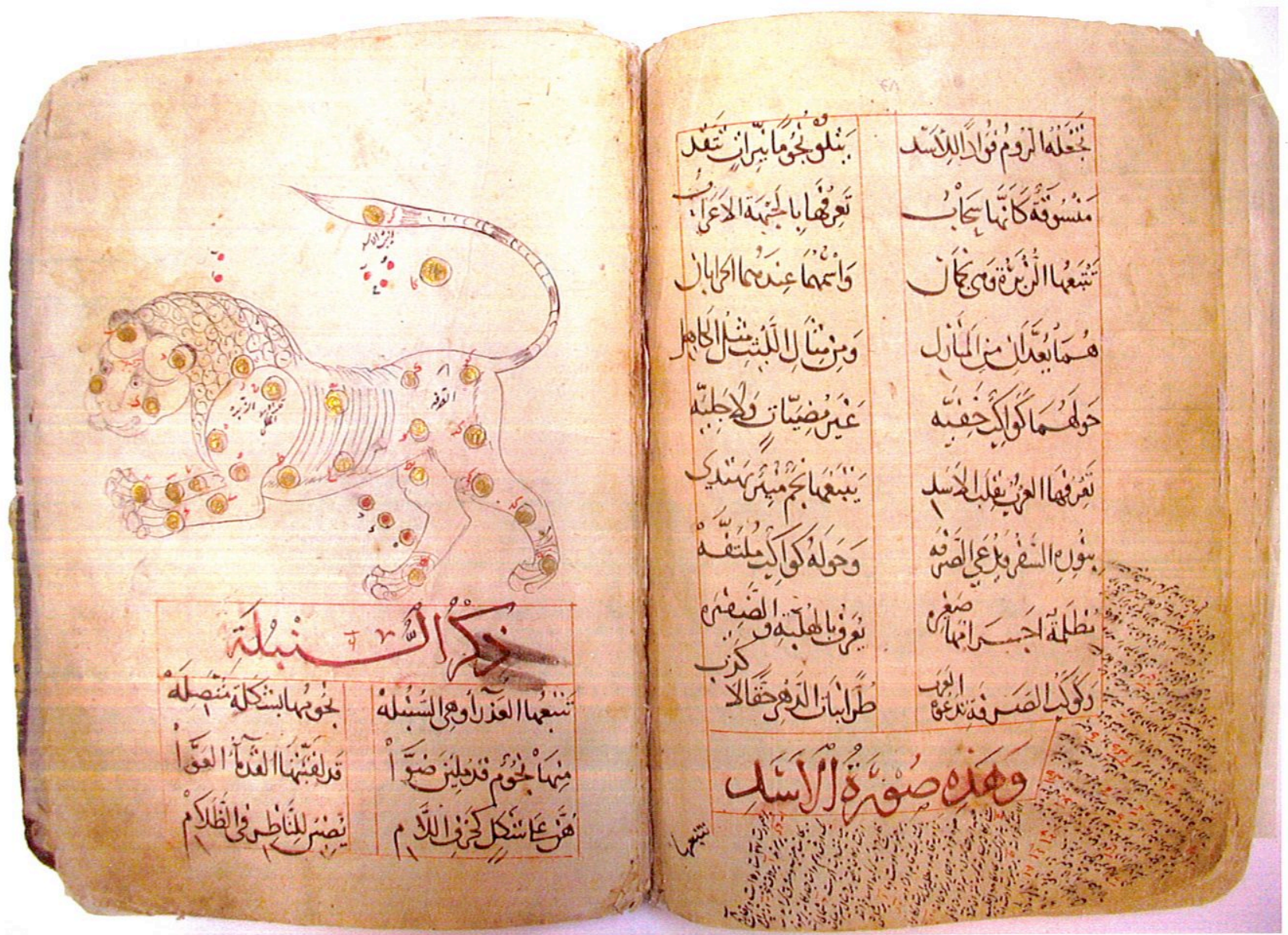

Fig. 16. Leo. RAM Ibn al-Sufi, pages 48-49. (Photo: Anna Contadini, courtesy of the Reza Abbasi Muscum, Tehran)

manuscripts of the Maqāmāt, one dated 634 (1237) and another, now in St. Petersburg, that closely resembles it (figs. 28, 29). ${ }^{30}$ The latter is unfortunately undated, but it is reasonable to assume that it is the earlier of the two, its miniatures showing experimental features that are then handled more confidently in the 1237 manuscript. Accordingly, it has been assigned to ca. $1230-35 .^{31}$

As for provenance, the 1237 Maqāmàt is usually attributed to Baghdad, on the rather dubious grounds that its compiler and painter has the nisba al-Wasiti, on which basis he is assumed to have worked in Baghdad. ${ }^{32}$ The case is strengthened somewhat, however, by the sumptuousness of the miniatures in this manuscript and the high quality of its calligraphy, which are consonant with a royal commission and increase the likelihood of production in a capi- tal city. Because of the close resemblances between it and the St. Petersburg Maqāmāt, the latter is also usually thought to have been produced in Baghdad. But other manuscripts in the early-thirteenth-century group have a different provenance: the Mar Mattai Gospel book was produced in the monastery of Mar Mattai near Mosul; for various reasons the $\mathrm{Na}$ 't too can be confidently attributed to a North Jaziran environment to which the 1224 Dioscorides, because of its strong similarities to the $N a^{c} t$, can reasonably be assigned as well. Thus, although the possibility of a Baghdad provenance cannot be completely excluded for the Reza Abbasi Museum urjüza, it is clear that the particularly close relationship of its visual components with those of the $\mathrm{Na}^{c} t$ point to the greater likelihood of a center of production in the North Jazira, probably in the Mosul region. 


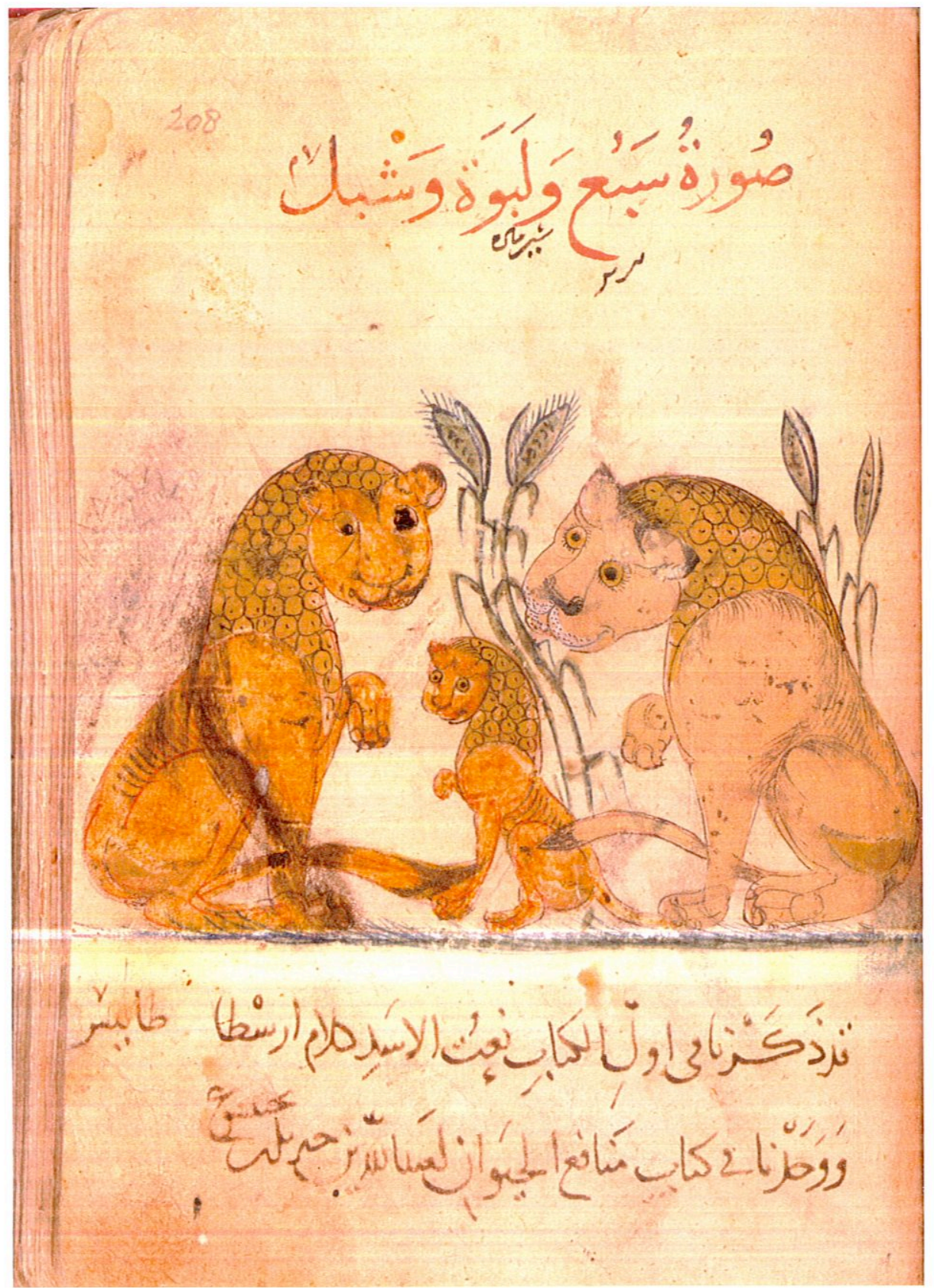

Fig. 17. Lions. British Library $\mathrm{Na}^{\mathrm{c} t}$, folio 208r. (Photo @ the British Library) 


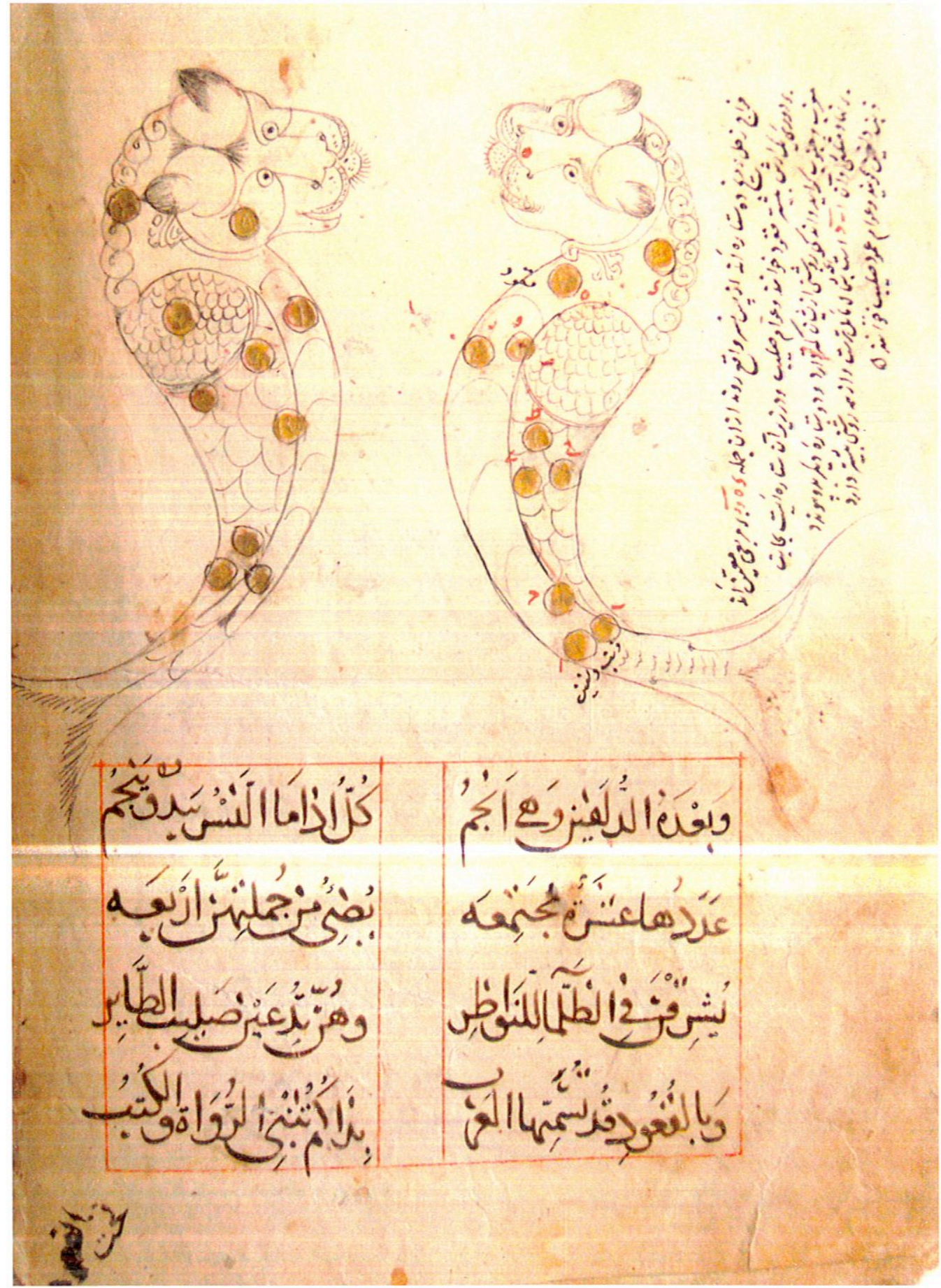

Fig. 18. Delphinus. RAM Ibn al-Sufi, page 32. (Photo: Anna Contadini, courtesy of the Reza Abbasi Museum, Tehran) 

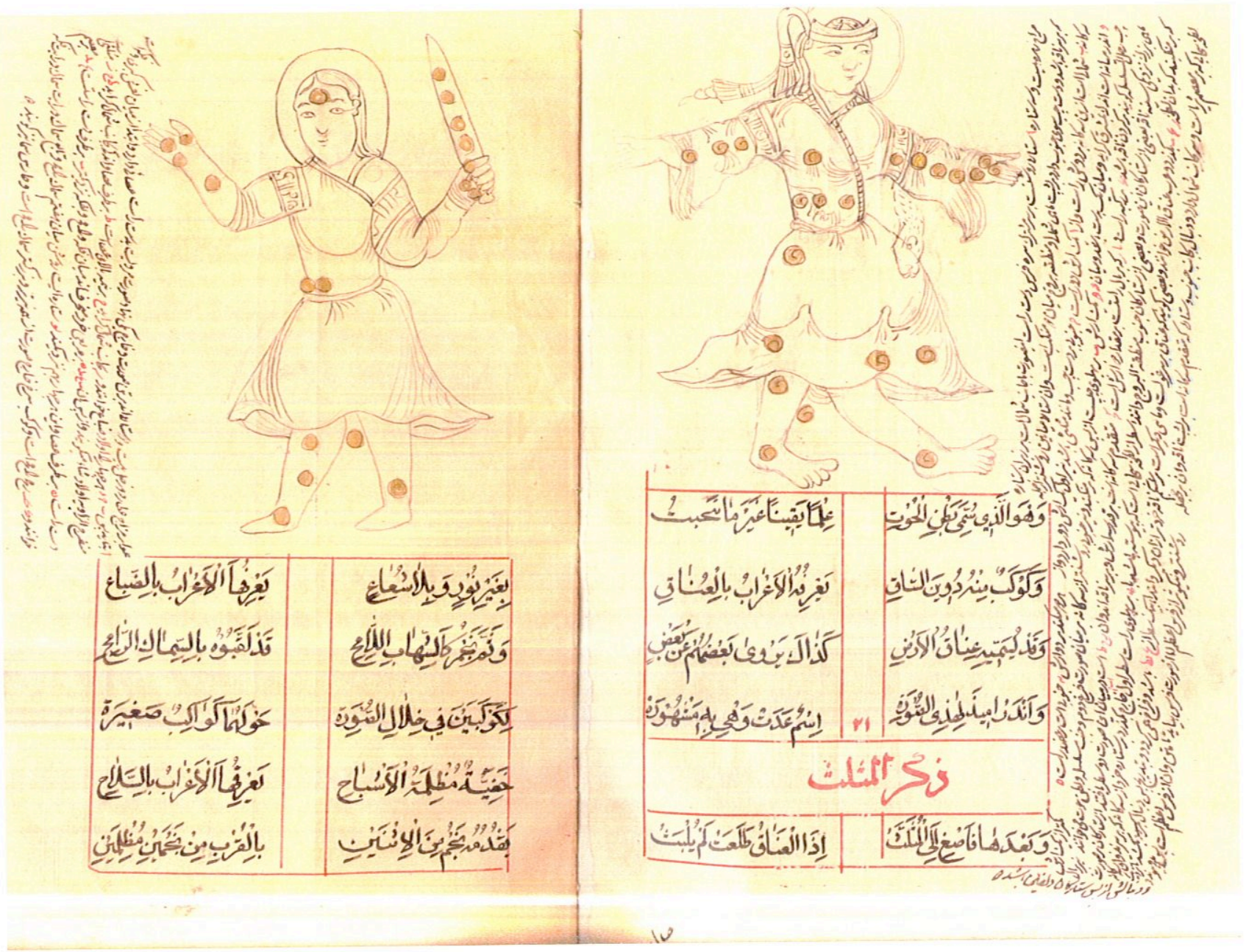

Fig. 19. Andromeda (right) and Bootes (left). Majlis Library Qajar copy, page 10. (Photo: courtesy of the Majlis Library, Tehran) 


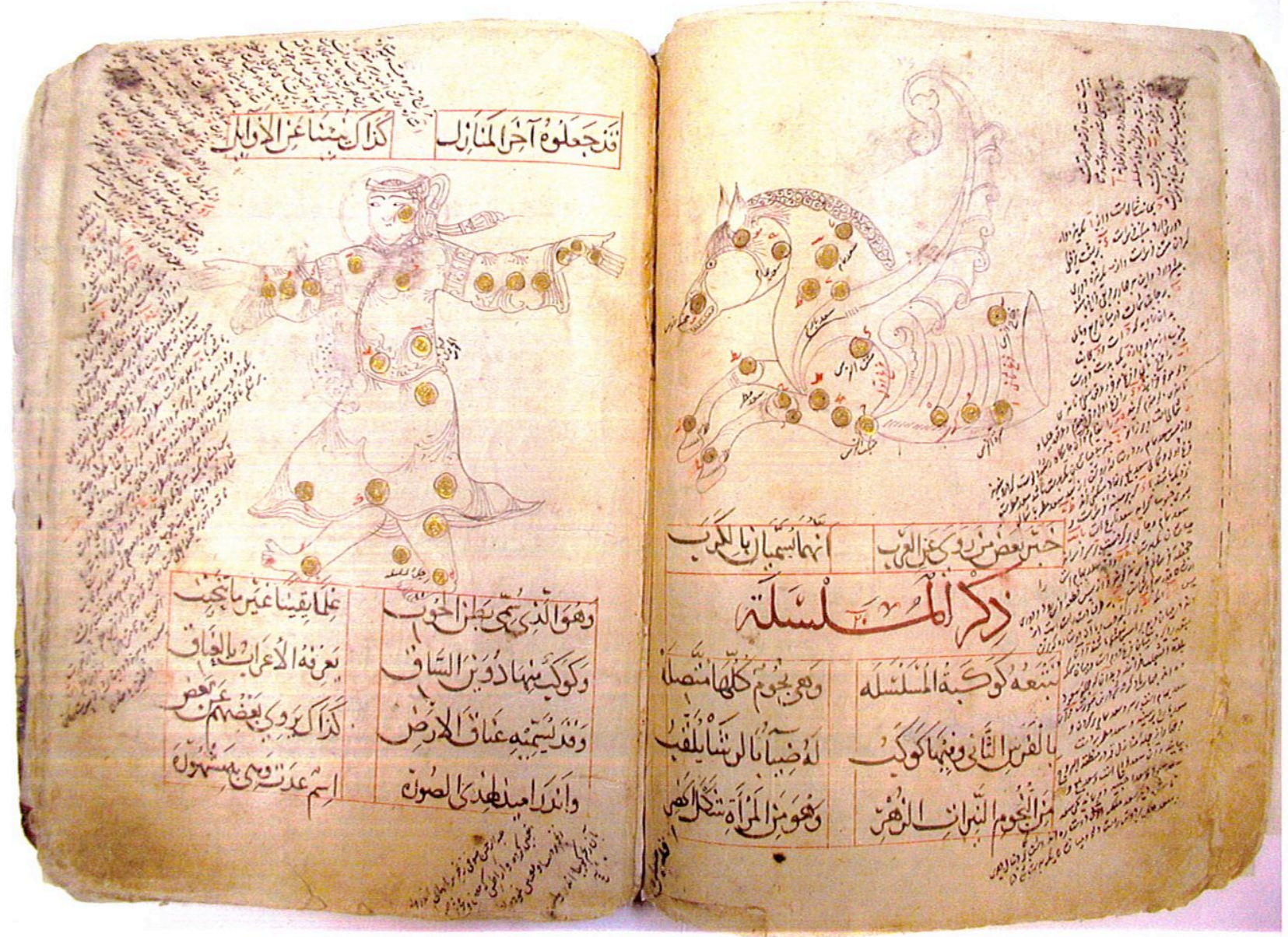

Fig. 20. Pegasus (right) and Andromeda (left). RAM Ibn al-Sufi, pages 36-37. (Photo: Anna Contadini, courtesy of the Reza Abbasi Museum, Tehran) 


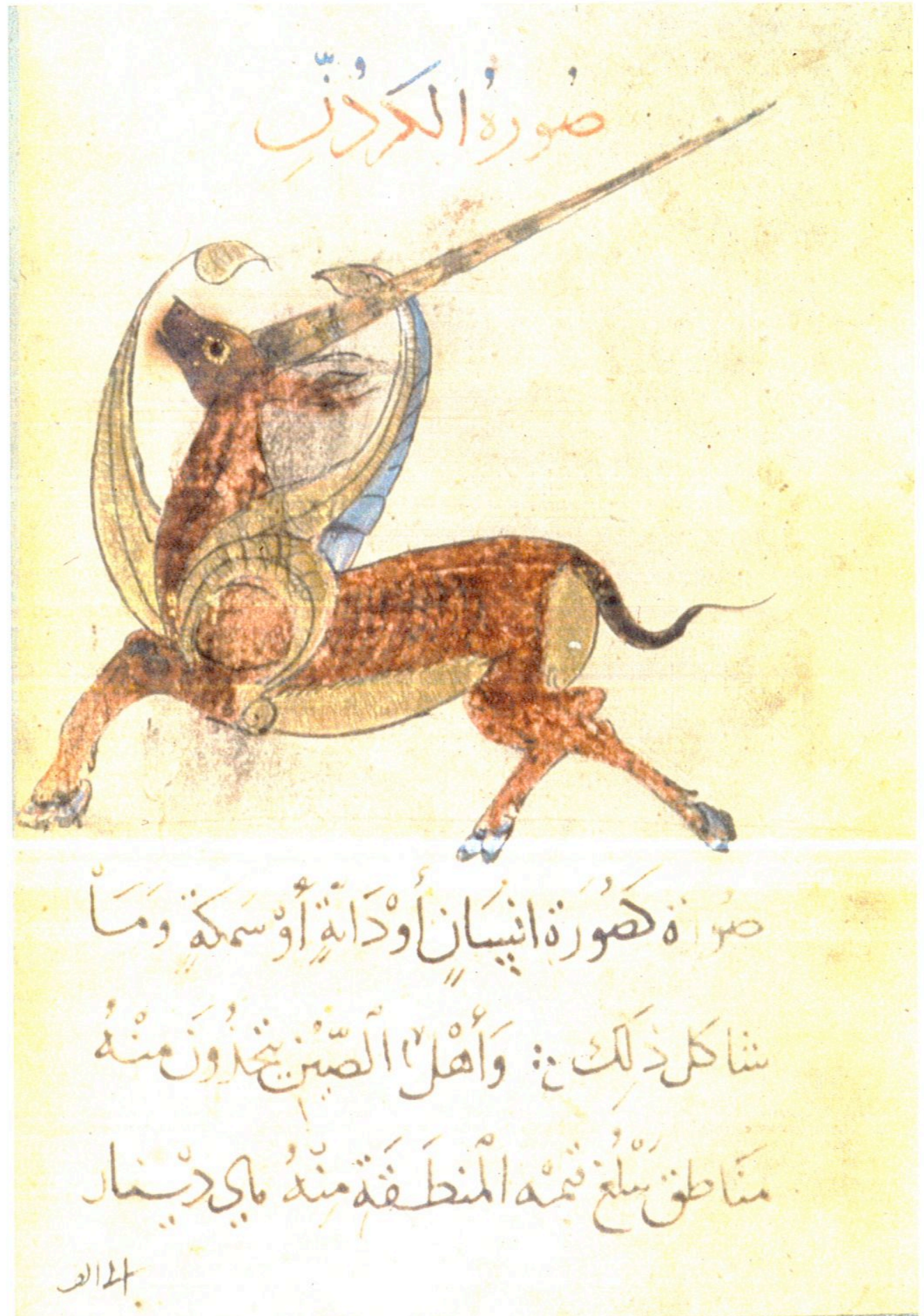

Fig. 21. Unicorn. British Library $\mathrm{Na}^{\mathrm{c}} \mathrm{t}$, folio $197 \mathrm{v}$. (Photo @ 


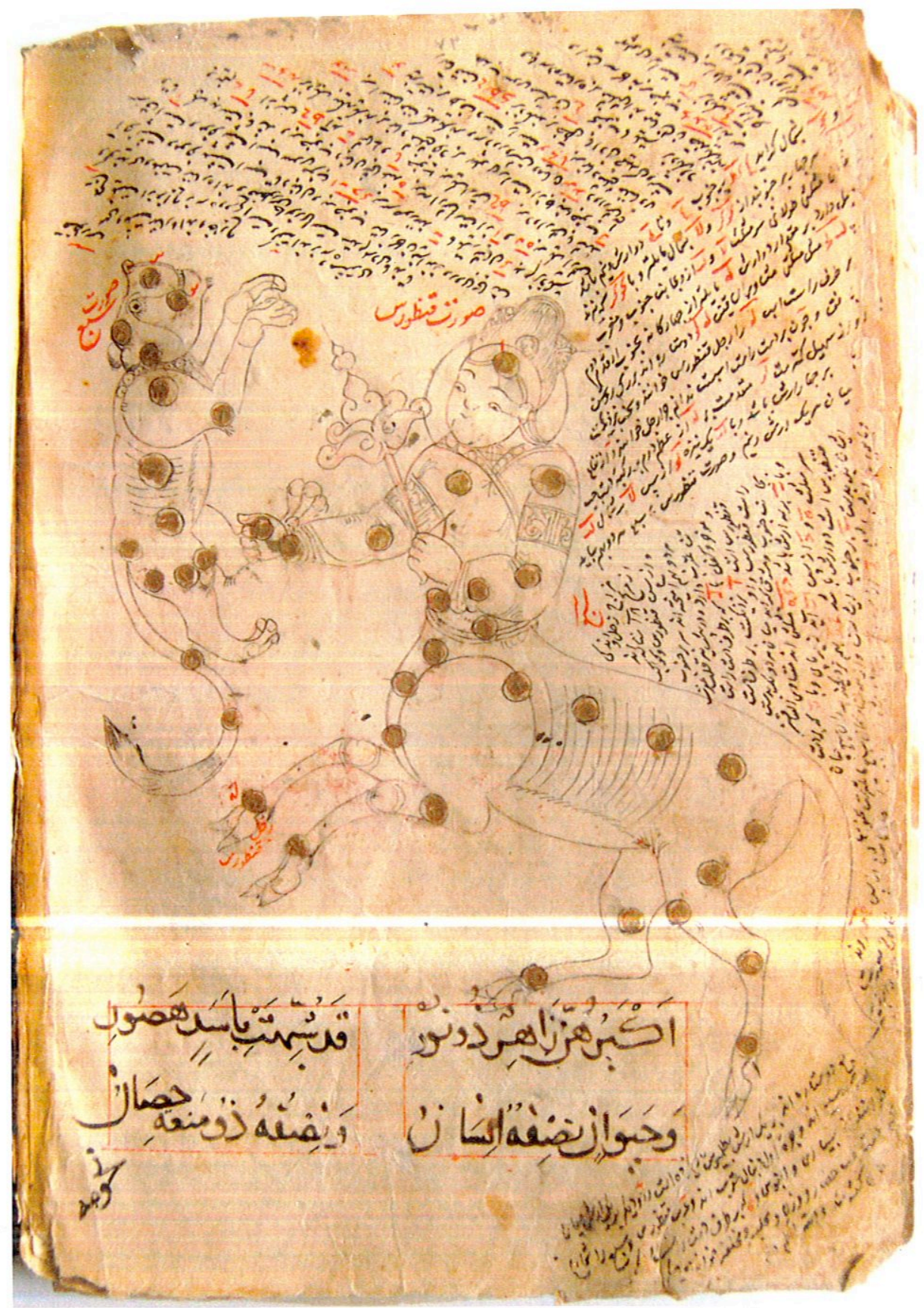

Fig. 22. Centaurus with Lupus. RAM Ibn al-Sufi, page 72. (Photo: Anna Contadini, courtesy of the Reza Abbasi Museum, Tehran) 

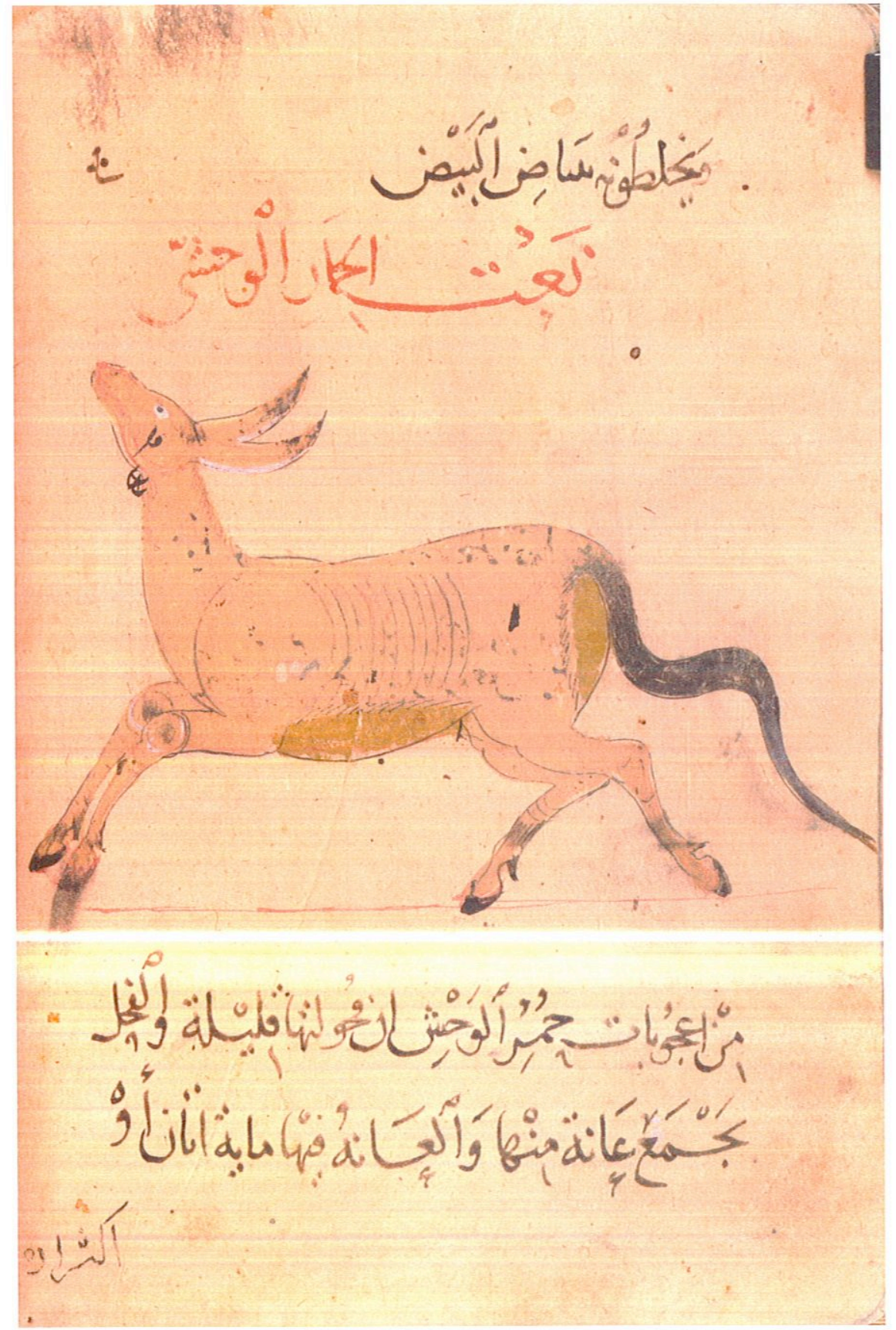

Fig. 23. Onager. British Library Na't, folio 15lv. (Photo @ the British Library) 


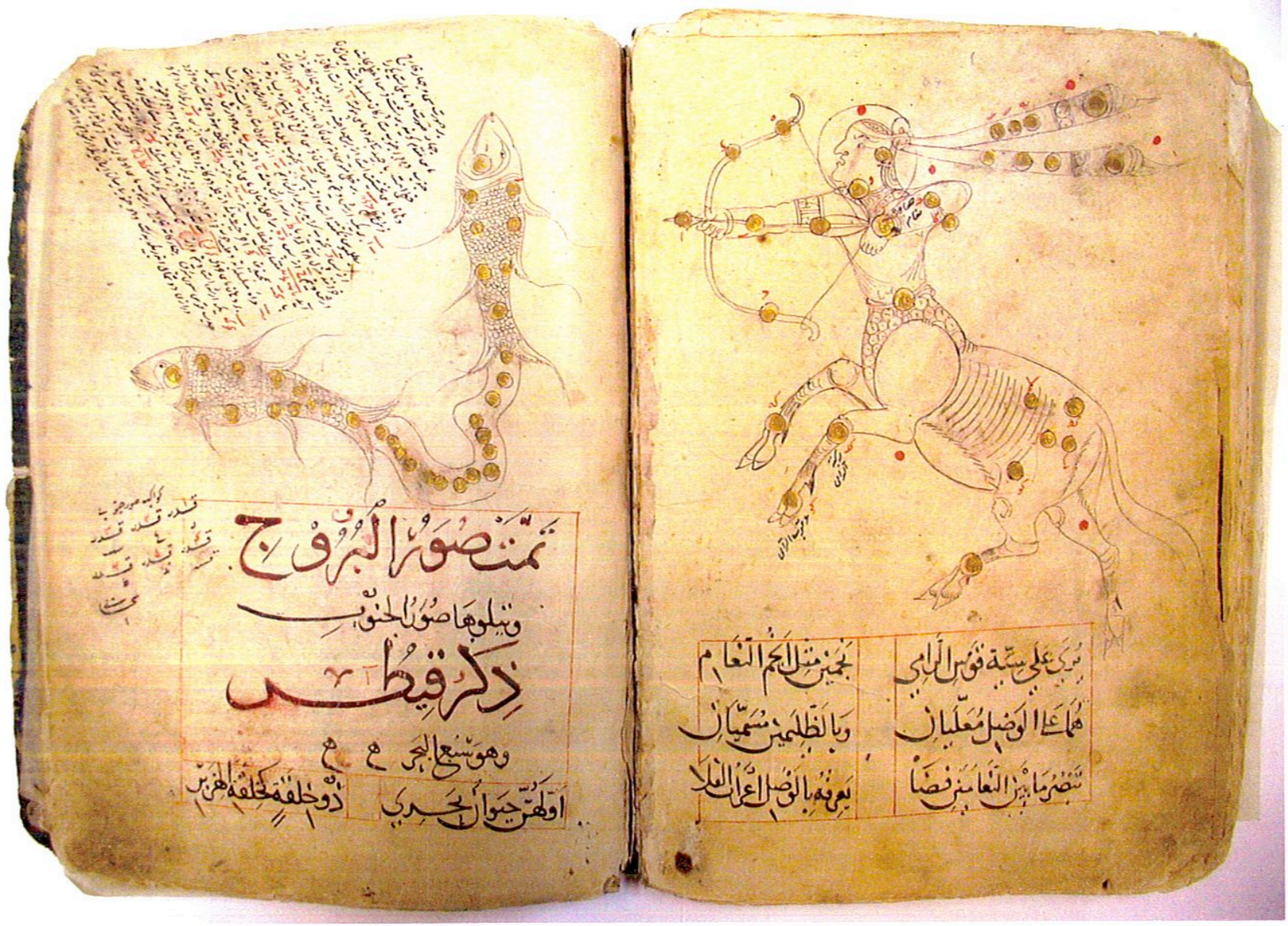

Fig. 24. Sagittarius (right) and Pisces (left). RAM Ibn al-Sufi, pages 56-57. (Photo: Anna Contadini, courtesy of the Reza Abbasi Museum, Tehran) 


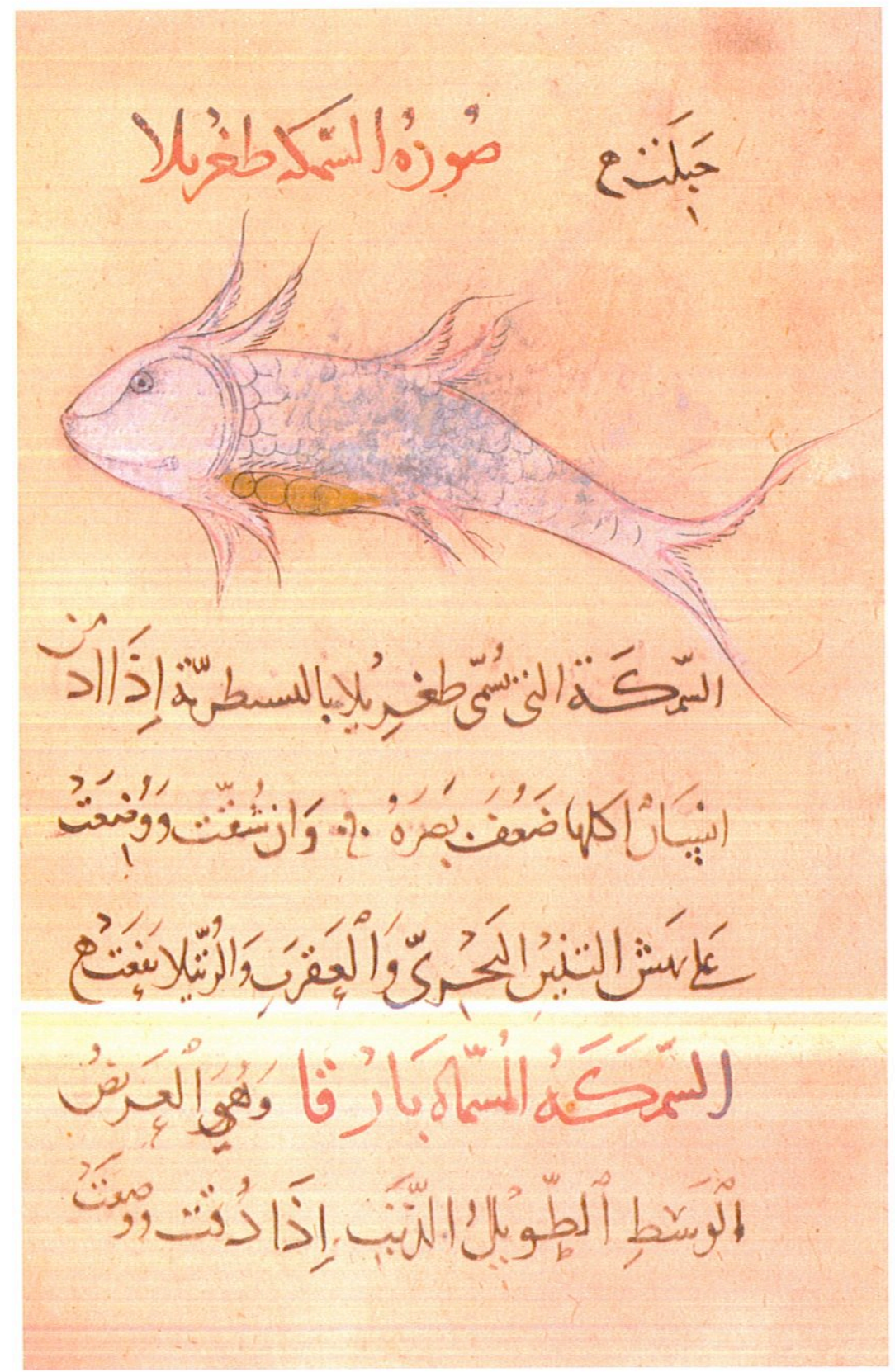

Fig. 25. Mullet. British Library Nact, folio 74v. (Photo @ the British Library) 


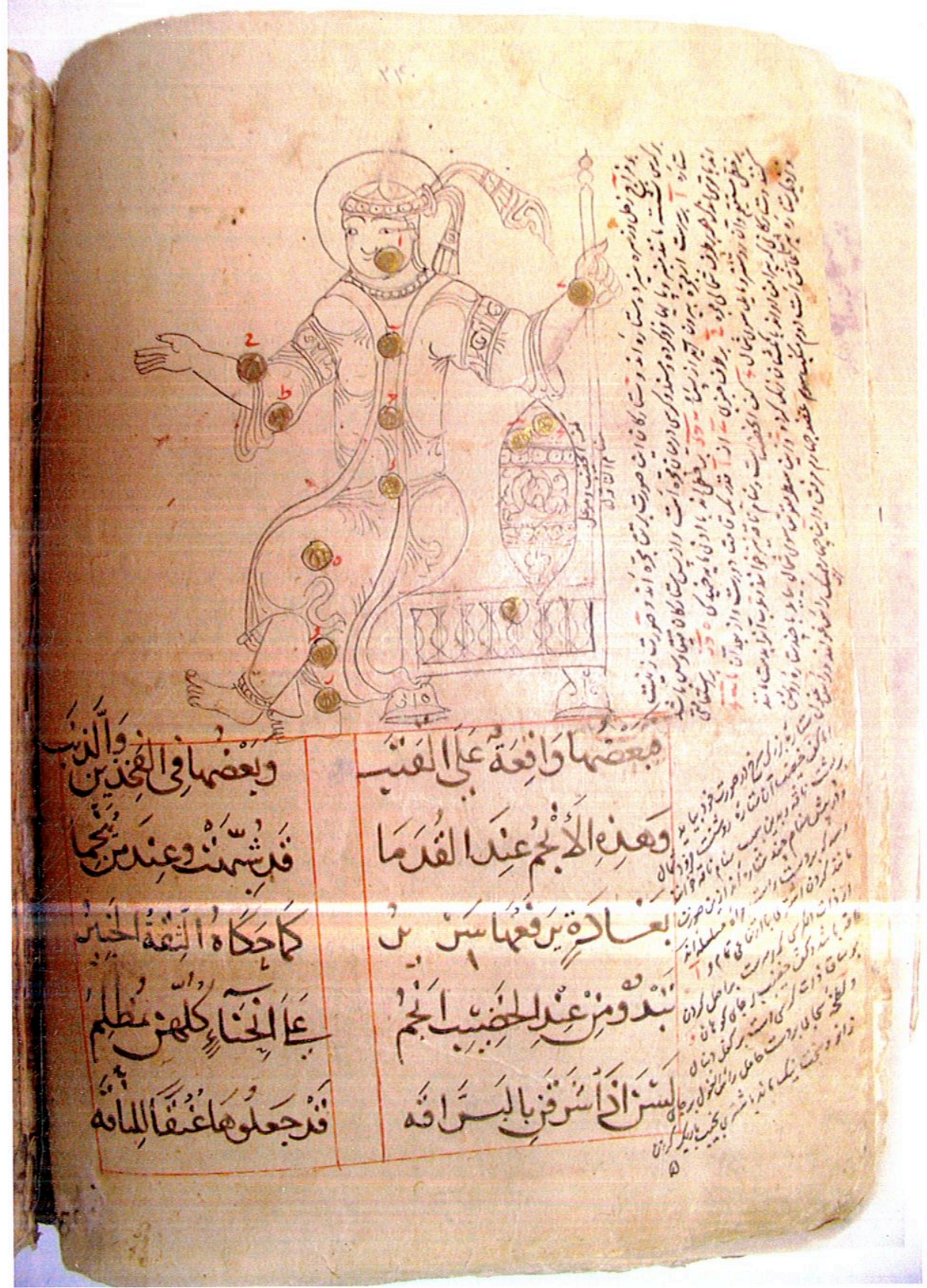

Fig. 26. Cassiopeia. RAM Ibn al-Sufi, page 24. (Photo: Anna Contadini, courtesy of the Reza Abbasi Museum, Tehran) 


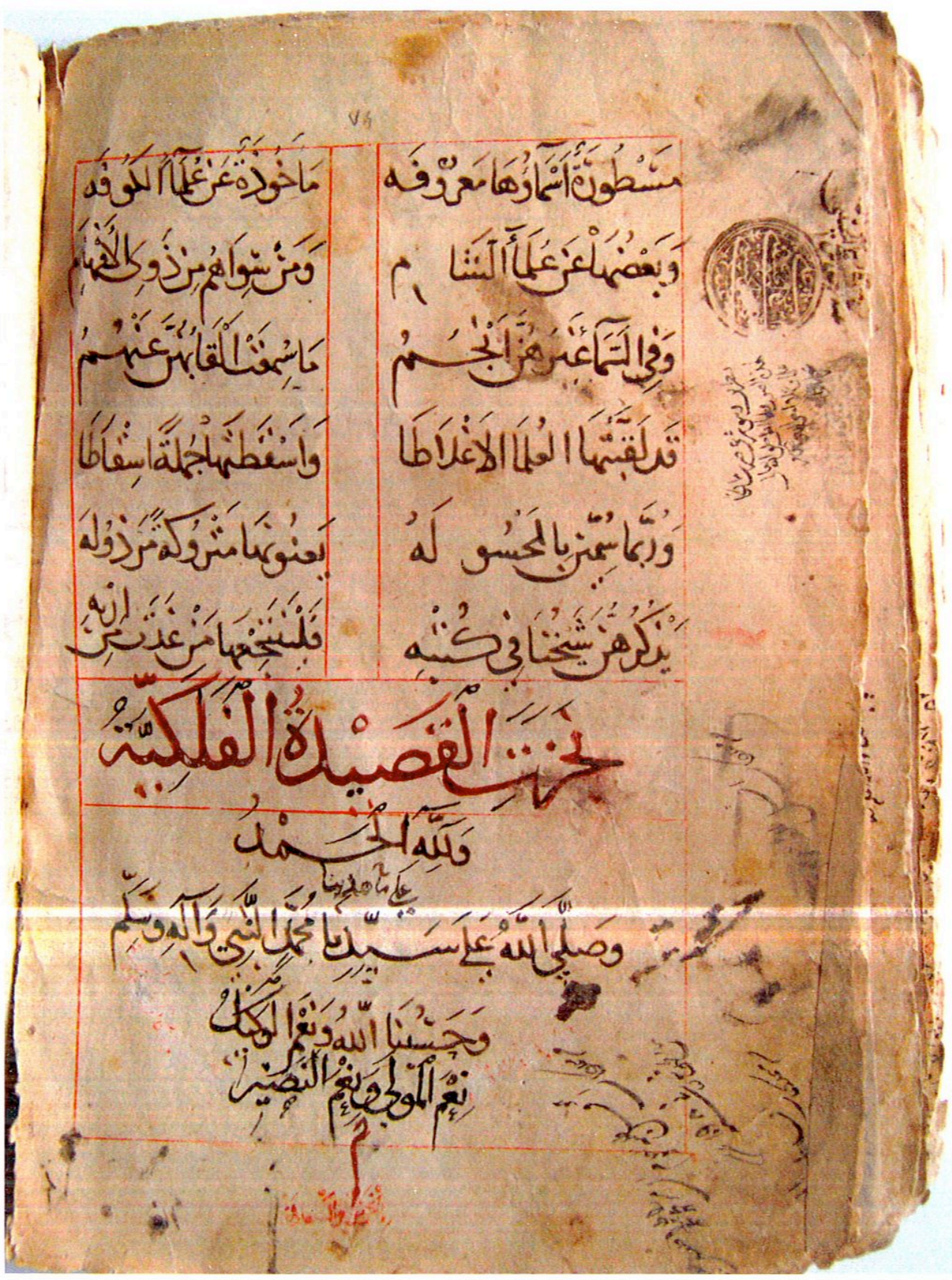

Fig. 27. Colophon. RAM Ibn al-Sufi, page 76. (Photo: Anna Contadini, courtesy of the Reza Abbasi Muscum, Tehran) 


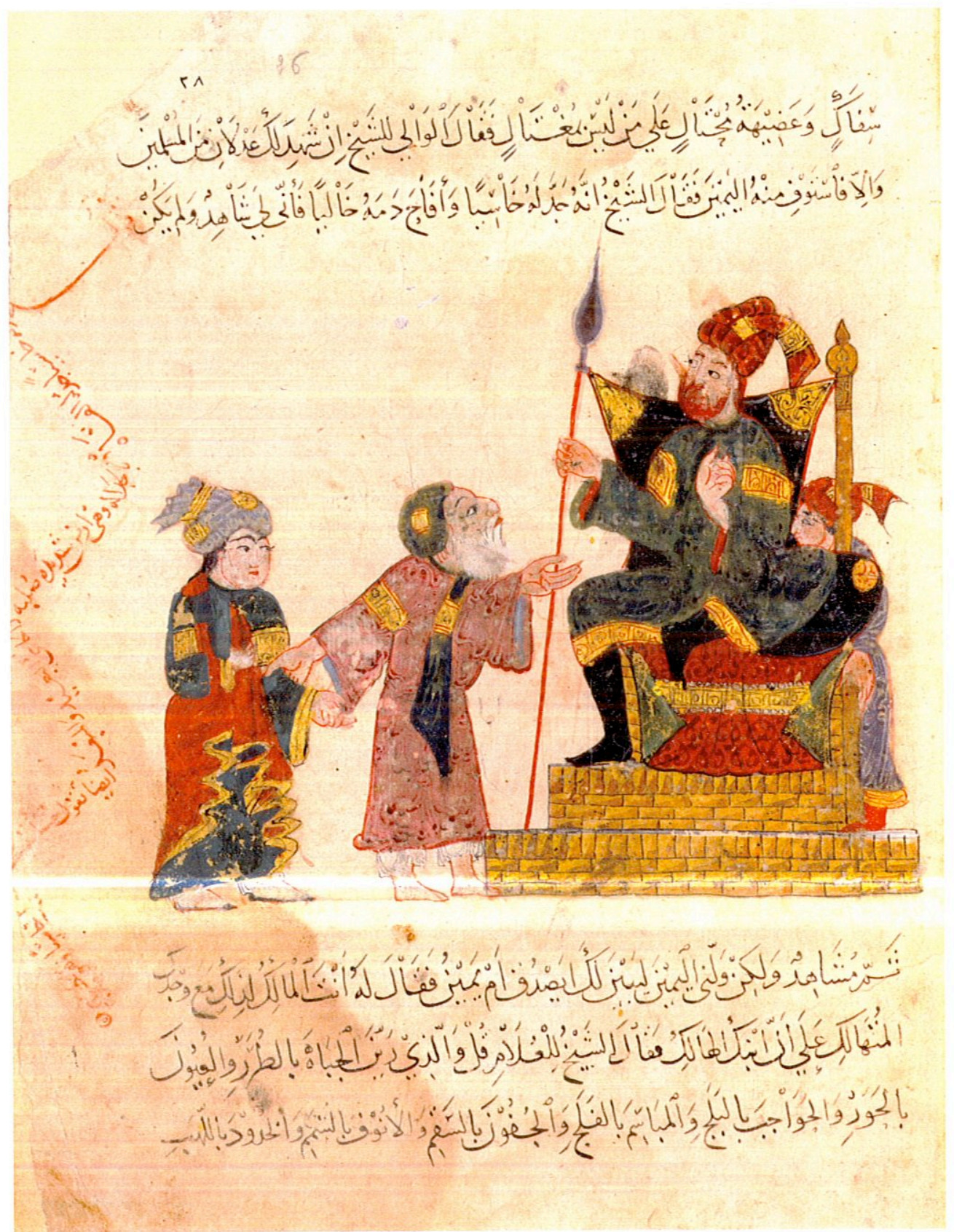

Fig. 28. Abu Zayd before the governor of Rahba. Al-Hariri, Maqāmāt, dated 634 (1237), probably Baghdad. Paris, Bibliothèque nationale de France, ms. arabe 5847, folio 26r. (Photo (c) the Bibliothèque nationale de France) 


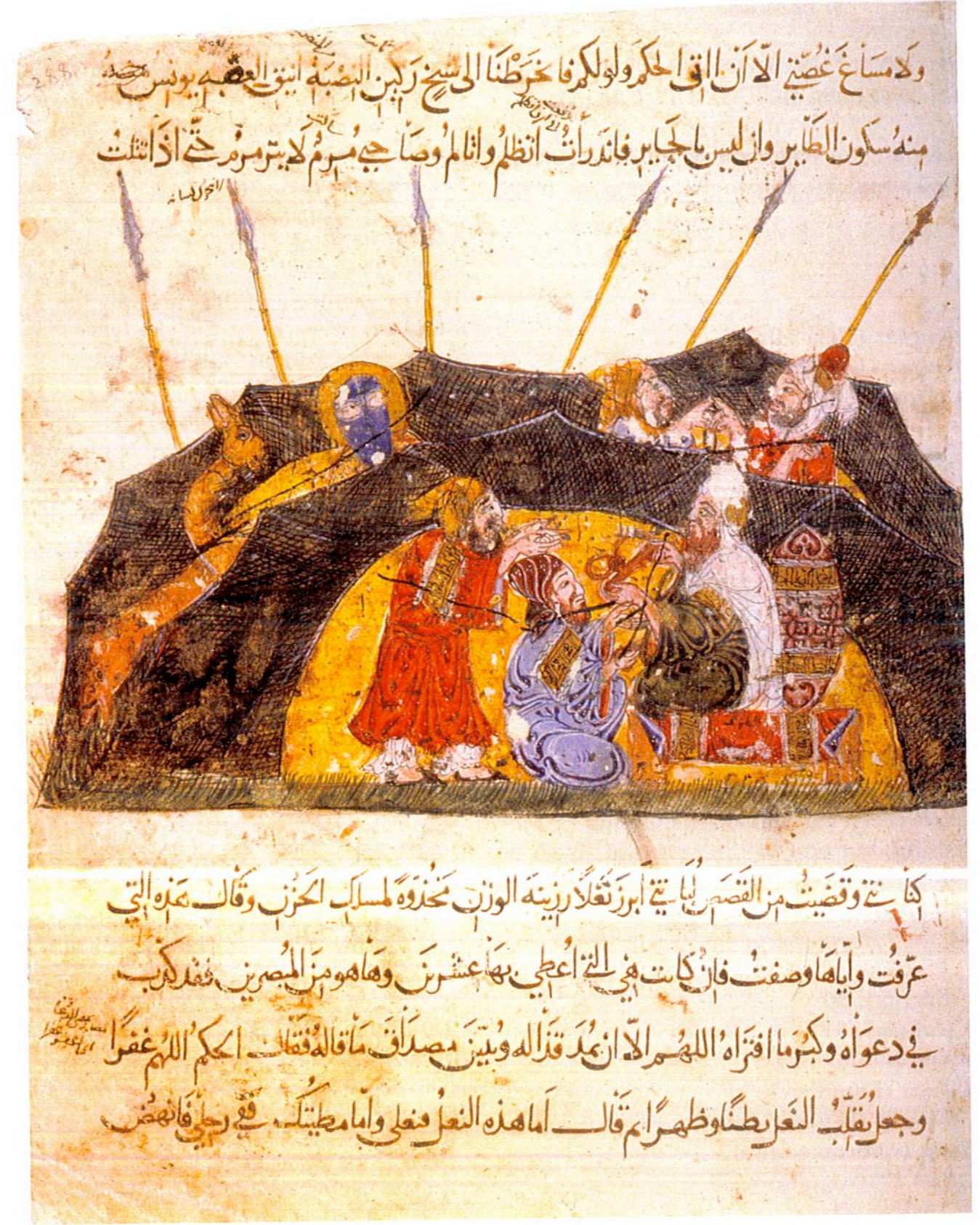

Fig. 29. The case of the lost mount. Al-Hariri, Maquämāt, ca. 1225-30, probably Baghdad. St. Petersburg, Academy of Sciences, ms. S 23, page 288 (folio 145r). (After Pétrosyan, ed., De Bagdad à Ispahan, 126) 


\section{APPENDIX}

\section{CONTENTS AND ILLUSTRATIONS OF THE REZA ABBASI MUSEUM IBN AL-SUFI URJŪZA}

Numbers refer to the pages on which illustrations occur. Asterisks indicate missing drawings or texts, as specified.

Frontispiece, 2

Frontispiece, 3

1. al-Dubb al-asghar (Ursa Minor), 5

2. al-Dubb al-akbar (Ursa Major), 6

3. al-Timnin (Draco), 11

4. Qayqāwus (Cepheus), 14

5. al-'Awwà (Bootes), 16

6. al-Iklêl al-shimālì/al-Fakka (Corona Borealis), 19

7. al-jâthì 'alä rukbatayhi (Hercules, but with picture of Orion instead of Hercules, who is depicted on 60), 20

8. al-Sulyāq (or al-Shulyāq or al-Sulahfāh) (Lyra or Tortoise), picture and end of text (two lines), 22. The preceding text and title are to be found on 61 . The whole section in the right sequence and with the right pictures is found in the Qajar copy, 12-13.

9. al-Tä̉ir/al-Dajjāja (Cvgnus), 23

10. Dhät al-kursì (Cassiopeia), 24

*11. Birshäwush (Perseus), missing beginning of section and drawing, but end of the text (ten lines) is found on 25

12. al-'Ayyüq/Mumsik al-a'inna (Auriga), 26

13. al-Hawwa' wa 'l-Hayya (Serpentarius and Serpens), 29

14. al-Sahm (Sagitta), 30

15. al-'Uqāb (Aquila), 31

16. al-Dulfin (Delphinus), 32

17. Qat 'at al-faras (Equuleus), 33

18. al-Faras al-a'zam (Pegasus), 36

19. al-Musalsala (Andromeda), 37

20. al-Muthallath (Triangulum), 38

21. al-Hamal (Aries), 41

22. al-Thawr (Taurus), 43

23. al-Jawzä (Gemini), 45

24. al-Saratān (Cancer), 46

25. al-Asad (Leo), 49

26. al-Sunbula (Virgo), 50

27. al-Mīzān (Libra), 52

28. al-Aqrab (Scorpius), 54

29. al-Qaws (Sagittarius), 56
*30. al-jady (Capricornus), missing section and drawing

*31. al-Dalw/Sākib (Aquarius), missing section and drawing

32. al-Hūt/al-Samakatayn (Pisces), missing part of section, but drawing on 57

33. Qìtus (Cetus), 58

34. al-Jabbār/al-Jazuza' (Orion, but with picture of Hercules instead of Orion, who is depicted on 20), 60; followed by al-Sulyāq (Lyra), title and five lines of text, 61. The picture and the continuation of the text are found on 22.

35. al-Nahr (Eridanus), 62

36. al-Amab (Lepus), 63

*37. al-Kalb al-akbar (Canis Major), title and one line of text, but the rest of the section and drawing are missing

*38. al-Kalb al-asghar (Canis Minor), missing section and drawing

39. al-Safina (Argo Navis), 64

40. al-Shujāac (Hydra), 66

41. al-Bātiva (Crater), 70

42. al-Ghurāb (Corvus), 71

43. Qanțuris wa-Sab' (Centaurus and Lupus), 72

44. al-Mijmara (Ara), 73

45. al-Iklēl al-janūbì (Corona Australis), 74

46. al-Hūt al-janūbì (Piscis Austrinus), 75

\section{NOTES}

Author's note: I should like to thank the Faculty of Arts and Humanities of SOAS for sponsoring my trip to Tehran to study the manuscripts there. I am very grateful to Mrs. Batool Ahmadi, the Director of the Reza Abbasi Museum, who gave me permission to study the Ibn al-Sufi manuscript, and to Ms. Tavebeh Ghodratabady. curator, for her kind help. I should also like to thank my friends and colleagues Abdullah Gouchani and Sheila Canby (who was my companion on this trip) for looking at the Ibn al-Sufi manuscript with me and for their insightful comments. Thanks are also due to Abdolhamid Keshmirshekan, who helped at an initial stage of the investigation on the RAM manuscript. I am also grateful to the Director of the Majlis Library in Tehran, Hojjatol Eslam Abhari, and the Keeper of Manuscripts, Prof. Abdul Hussevn Haeri, for permission and help in studying the Qajar copy. Majid Saeli was very kind in guiding me through the various sections of the Majlis Library, and Fariba Afkari prepared the way. My thanks are also due to Rebecca Foote, who gave me access to the al-Sufi manuscript of the National Museum in Qatar. I am also grateful to Prof. Abdel Haleem, of SOAS, for discussing with me the date found in the RAM manuscript, and Alexander Morton, who discussed with me the date, commentary, and seal impressions in the same manuscript. Prof. Charles Burnett, of the Warburg Institute, kindly read a draft of this article, and $I$ 
am grateful for his helpful comments. For the other manuscripts mentioned in the article, both in the main text and the notes, I should like to thank again the British Library, the Freer Gallery of Art in Washington, the Bibliothèque nationale de France, the Süleymaniye Library and the Topkapı Sarayı Library in Istanbul, the Bodleian Library in Oxford, the Staatsbibliothek in Berlin, and the Vatican Library.

1. Tehran, Reza Abbasi Museum, M. 570. For this manuscript, see M. Mahboubian, Treasures of Persian Art after Islam: The Mahboubian Collection (New York, 1970), introduction and no. 913, where a brief description and a list of the miniatures are provided and five images are reproduced in black and white. The manuscript has been the subject of a general article by G. Aziz-zada, "Urjūza yā Risālat al-Sūfí fi 'l-kawākib," Mūzihhã 31 [n.p., 10], 1381/2002): 12-14 (Persian text), where a more detailed description and a discussion of the date, author, and patron of the manuscript are found. A number of color images from this manuscript are published with discursive captions in N. Pourjavady, ed., The Splendour of Iran, 3 vols. (Loṇdon: Booth-Clibborn Editions, 2001), vol. 3, 267-73. (This reference was brought to my attention by Moya Carey while she was my research assistant; for her work on al-Sufi manuscripts, see notes 3 and 8 , below. She has also started building up research material on the Ibn al-Sufi tradition.) Although the captions of the Pourjavady book carry a general attribution of the manuscript to the twelfth century, one of them (269), which accompanies a reproduction of one of the frontispieces, a portrait said to be of al-Sufi, describes the figure's profile as being "characteristic of the 'Baghdad School of the early 13 th century."

2. British Library, Or. 2784. For this manuscript, see A. Contadini, "The Kitāb Na't al-Hayawàn (Book on the Characteristics of Animals, British Library, Or. 2784) and the 'Ibn Bakhtishū" Illustrated Bestiaries" (PhD thesis, SOAS, University of London, 1992) and, further, K. Holter, "Die islamischen Miniatuhandichriften wor 1350." Tomtralblatt fü Bibliothetsesen 54. 1-2 (1937): 1-34. 14. no. 33 (where the work is mistitled); H. Buchthal, O. Kurz, and R. Ettinghausen, "Supplementary Notes to K. Holter's 'Check List of Islamic Illuminated Manuscripts Before A.D. 1350, "' Ars Islamica 7 (1940): 147-64, 153, no. 33; H. Buchthal, "Early Islamic Miniatures from Baghdād," The Joumal of the Walters Art Gallery 5 (1942): 19-39 and figs. 34-36, 39, 41; R. Ettinghausen, Arab Painting (Geneva, 1962), 136-37: A. Contadini, "The Ibn Buhtīshū Bestiary Tradition: The Text and Its Sources," Medicina nei Secoli: Arte e Scienza 6, 2 (1994): 349-64; A. Contadini, "A Bestiary Tale: Text and Image of the Unicorn in the Kitāb Nát al-Hayawãn (British Library, Or. 2784)," Muqarnas 20 (2003): 17-33; A. Contadini, "Musical Beasts: The SwanPhoenix in the Ibn Bakhtishu' Bestiaries," in The Iconography of Islamic Art: Studies in Honour of Robert Hillenbrand, ed. B. O'Kane (Edinburgh: Edinburgh University Press, 2004), 93-101. The discussion on the relationships between the $\mathrm{RAM}$ Ibn al-Sufi, the $\mathrm{Na}$ \% , and other Arabic manuscripts will be developed further in A. Contadini, A World of Beasts: Arab and Persian Books on Animals, 13 th to 14 th centuries, forthcoming.

3. The term qasida is used on the last page of the RAM manuscript, in the title of the colophon: najazat al-qasida al-falakiysa ("The poem of the heavenly spheres is completed"); it also appears in the 519 (1125) manuscript now in the collection of the National Museum of Qatar, MI-02-98-80, which consists of the Kitāb Suwar al-kawäkib al-thābita with the urjüza following it. See Sotheby's, Oriental Manuscripts and Miniatures (London, sale IN8256, Apr. 29, 1998), lot 34, 32-48 (a long and comprehensive entry by D. A King, B. Brend, and R. Hillenbrand). The title page of the urjuza (fol. 162r) reads

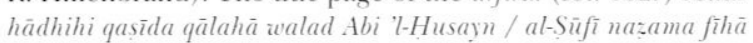
mä natharahu abühu li-yashal / hîz dhälika 'alà man rāmahu ("this qasida has been composed by the son of Abu' l-Husayn al-Sufi, who has put into verse what his father had written in prose, so that for those who wish it should be easier to memorize"). Moya Carey has written an entry on this manuscript for a forthcoming catalogue of the collection of the Qatar museum.

4. For the urjüza genre, see M. Ullmann, Untersuchungen zur Raǵazpoesie (Wiesbaden, 1966), especially 56-57, and G. Endress, "Das Lehrgedicht," in H. Gätje, ed., Grundriss der arabischen Philologie, Band II: Literaturvissenschaft (Wiesbaden, 1987), 471-73, where these authors have indicated the range of subject matter on which urjüzas are written. See also W. Heinrichs, s.v. "Radjaz," Encyclopaedia of Islam, new ed. (Leiden: Brill, 1960-2004) (henceforth E/2). For a music ưjūza, see al-Khātib al-Irbilī, "Jawāhir al-nizām fĩ ma rifat alanghām, dated 729/1328," in al-Mashriq 16, 1913: 895-901. For didactic poetry in both Arabic and Latin literature, see C. Burnett, "Learned Knowledge of Arabic Poetry, Rhymed Prose, and Didactic Verse from Petrus Alfonsi to Petrarch," in J. Marenbon, ed., Poetry and Philosophy in the Middle Ages: A Festschrift for Peter Dronke (Leiden: Brill, 2001), 29-62, especially $42-47$.

5. There seems to be no tradition of illustrating exclusively the Arab forms of the constellations, although in exceptional cases the Greek and the Arab forms are conflated in miniatures. For example, in the 1171 al-Sufi manuscript in the Bodleian I.ibraty, Ms. Hunt 212. fol. 40s, we find a picture of Casciopeia as a woman seated on a chatr and a camel figure dram across her. See E. Savage-Smith, "Celestial Mapping," in J. B. Harley and D. Woodward, eds.. The Histony of Cartography: Cartography in the Traditional Islamic and South Asian Societies, 2 vols. (Chicago, 1987-), vol. 2, bk. 1 (1992), 52, fig. 2.34. I am grateful to Dr. Colin Wakefield of the Bodleian Library for recently showing me again this fragile manuscript.

6. The ink has a tone of brown different from that of the main text and is also of a lesser quality, as it has rubbed off in some places.

7. Abu 'l-Husavn 'Abd al-Rahmān al-Sūfī, Suwaru'l-Kawàkì or (Uranometn) (Description of the 48 Constellations): Arabic lext, with the Urjüza of Ibnu's-Süfi, Edited from the Oldest Extant Manuscript and Based on the Ulugh Beg Royal Codex (Bibliotheque Nationale, Paris, Arabe 5036) by M. Nizämu'd-Dìn (henceforth Hyderabad ed.) (Hyderabad 1373/1954), 3. This edition, made in Hyderabad, is mainly based on the Oxford manuscript Marsh 144, dated 400 (1009), and that of Ulugh Beg, Bibliothèque nationale, Arabe 5036, datable to the midfifteenth century.

8. See S. M. Stern, s.v. "al-Süfĩ," in EI2, with fundamental bibliography. See also E. Wellesz, "An Early al-Süfī Manuscript in the Bodleian Library in Oxford: A Study in Islamic Constellation Images," Ars Orientalis 3 (1959): 1-26; idem, "Islamic 
Astronomical Imagery: Classical and Bedouin Tradition," Oriental Art 10, 2 (1964): 85-91; P. Kunitzsch, "The Astonomer Abu 'l-Husayn al-Süfi and His Book on the Constellations," in F. Sezgin, ed., Zeitschrift für Geschichte der Arabischislamischen Wissenschaften 3 (1986): 56-81; E. Savage-Smith, "The Islamic Tradition of Celestial Mapping," Asian Art 5, 4 (1992), 5-27; M. Carey, "Painting the Stars in a Century of Change: A Thirteenth-Century Copy of al-Sufi's Treatise on the Fixed Stars, British Library Or. 5323" (PhD thesis, SOAS, University of London, 2001); M. Carey, "Mapping the Mnemonic: A Late Thirteenth-Century Copy of al-Sufi's Book on the Constellations," in A. Contadini, ed., Arab Painting: Artistic Treasures from the Islamic World (London, forthcoming 2007). For very useful studies on the terminology of constellations and of al-Sufi's text, see P. Kunitzsch, Untersuchungen zur Sternnomenklatur der Araber (Wiesbaden, 1961); idem, Typen von Sternverzeichnissen in astronomischen Handschriften des zehnten bis vierzehnten Jahrhunderts (Wiesbaden, 1966).

9. C. Brockelmann, Geschichte der arabischen Literatur [supplement], 3 vols. (Leiden: E. J. Brill, 1937-42) (henceforth GAL/s), vol. 1, 863, and also 398; also see idem, Geschichte der arabischen Literatur, 2nd ed., 2 vols. (Leiden: E. J. Brill, 1945-49) (henceforth $G A L$ ), vol. 1, 253.

10. Brockelmann, $G A L$, vol. 1, 253; idem, $G A L / \mathrm{s}$, vol 1, 398; Stern, "al-Süfi," which cites the previous literature as weli.

11. Hyderabad ed.; Wellesz, "An Early al-Süfi Manuscript," 1, n. 2; F. Sezgin, Geschichte des arabischen Schriftums, Band VI: Astronomie (Leiden: E. J. Brill, 1978), 232, where it is also stated that Ibn al-Sufi wrote his urjüza in 371/981; Sotheby's, Oriental Manuscripts and Miniatures, 47; Aziz-zada, "Urjūza," 12.

12. Bodleian Library, Marsh 144. For this manuscript, see Wellesz, "An Early al-Süfi Manuscript"; E. Wellesz, An Islamic Book of Constellations, Bodleian Picture Books, no. 13 (Oxford: The Bodleian Library, 1965); Ettinghausen, Arab Painting, 52-53 and color pl. on 51: B. W. Robinson and B. Gray. eds.. The Pemian Ant of the Book, catalogue of an exhibition held at the Bodleian Library (Oxford, 1972), 9, no. 1.

13. This is also the reading in Aziz-zada, "Urjuza," 13. The ductus suggests al-Hasan, but what seems at first sight to be a tashdìd belonging to al-Rahmān on the line below is better read as the dots of the $y \vec{a}^{2}$ in Husayn.

14. I am grateful to Charles Burnett, who made this sensible point to me during our discussions on the manuscript.

15. Aziz-zada, "Urjūza," 13

16. See C. E. Bosworth, The New Islamic Dynasties (Edinburgh: Edinburgh University Press, 1996), 154-55.

17. Aziz-zada, "Urjūza," 13

18. Ibid. The manuscript is no. 5099 of the Majlis Library in Tehran, and the date is found in the colophon on page 76 (or folio 37 left); for this manuscript, see also C. Brockelmann, $G A L / \mathrm{s}$, vol. 1, 398, no. 11; Y. I'tisāmī et al., FïhristKitābkhāna-i Majlis-i Shürã-yi Millì (Tehran, 1933-), vol. 1, 109, no. 198 .

19. This is because al-Sufi wanted to represent one figure (that on the right) as seen from inside the celestial dome and the other (on the left) from the outside, as seen in celestial globes. See the explanation and passage from al-Sufi's text in Wellesz, "An Early al-Süfi Manuscript," 1-26 and pls. 127. on $4-5$.
20. Pourjavady, Splendour of Iran, 269, and Aziz-zada, "Urjūza," 13. For a discussion on frontispieces, see E. R. Hoffman, "The Author Portrait in Thirteenth-Century Arabic Manuscripts: A New Islamic Context for a Late-Antique Tradition," Muquarnas 10 (1993): 6-20.

21. al-Mubashshir, Mukhtār al-hikam wa mahäsin al-kalim (The Choicest Maxims and Best Savings), Syria (?), early 13th c., in Istanbul, Topkapı Sarayı Library, Ahmet III, 3206. For the text of this manuscript, see F. Rosenthal, "Arabische Nachrichten über Zenon den Eleaten," Orientalia 6 (1937): 21-67; and idem, "Al-Mubashshir ibn Fâtik: Prolegomena to an Abortive Edition," Oriens 13-14 (1961): 132-58. For this particular copy, see Ettinghausen, Arab Painting, 74-79 and color pls. on 75-77; D. James, Arab Painting: 358 A.H./ 969 A.D.-1112 A.H./1700 A.D (entire volume of Marg 29, 3 [1977]): 15; N. Nassar, "Saljuk or Byzantine: Two Related Styles of Jaziran Miniature Painting," in J. Raby, ed., The Ant of Syria and the Jazĩa 1100-1250, Oxford Studies in Islamic Art, vol. 1 (Oxford, 1985), 86, 88, 92, 94; J. M. Rogers, The Topkapr Saray Museum: The Albums and Illustrated Mamuscripts, Translated, Expanded, and Edited from the Turkish Original by Filiz Cağman and Zeren Tamende (Boston: Little, Brown, and Company, 1986), 32, no. 20 and color pl. 20; Hoffman, "The Author Portrait," 12-16 and fig. 2; L. A. Hunt, "The Commissioning of a Late Twelfth Century Gospel Book: The Frontispieces of MS Paris Bibl. Nat. Copte 13," in idem, Byzantium, Eastern Christendom and Islam: Art at the Crossroads of the Medieval Mediterranean, 2 vols. (London: Pindar Press, 1998), vol. 1, 149; L. A. Hunt, "Manuscript Production by Christians in 13th14th Century Greater Syria and Mesopotamia and Related Areas," in idem, Byzantium, Eastern Christendom and Islam, vol. 2, 158-59 and fig. 4; A. Contadini, "Ayyubid Illustrated Manuscripts and Their North Jaziran and Abbasid Neighbours," in R. Hillenbrand and S. Auld, eds., Ayyubid Jerusalem: The Holy City in Context, 1187-1250 (forthcoming).

22 Aziz-zada. "Uriūza." 13

23. Possibly Amir Sa d al-Din (fol. tr) : see color reproduction in Contadini, "The Kitäb Nat al-Hawayan," pl. 14. For the Dioscorides manuscript, Khawāss al-ashjār, dated 642/1244. Egypt(?), in Bologna, Biblioteca Universitaria, Cod. arab. 2954, see Buchthal, Kurz, and Eutinghausen, "Supplementary Notes," 162. no. 1: E. Grube, "Materialien zum Dioskurides Arabicus," in R. Ettinghausen, ed., Aus der Welt der islamischen Kunst: Festschrift für Emst Kühnel zum 75. Geburtstag am 26.10.1957 (Berlin, 1959), 163-94, 179, and figs. 15-17; Ettinghausen, Arab Painting, 66; F. Gabrieli and U. Scerrato Gli Arabi in Italia (Milan: Garzanti and Scheiwiller, 1979), color pls. 715-22; M. M. Sadek, The Arabic Materia Medica of Dioscorides (Quebec: Les Éditions du Sphinx, 1983), 18, no. VI; A. Touwaide, Farmacopea Araba Medievale: Codice Ayasofia 3703, 2 vols. (Milan: Antea, 1992, 79-80 and figs. 74-76; Contadini, "Ayyubid Illustrated Manuscripts." For Dioscorides in general, see A. Dietrich, Dioscurides Trumphans: Ein anonymer arabischer Kommentar (Ende 12. Jahrh. N. Ch.) zur Materia medica, 2 vols. (Göttingen: Vandenhoeck \& Ruprecht, 1988): J. M. Rogers, "The Arab Contribution to Botany and Pharmacology," Arab Affairs 6 (Spring 1988): 71-86; idem, "Text and Illustrations: Dioscorides and the Illustrated Herbal in the Arab Tradition," in Contadini, ed., Arab Painting, Sadek. Arabic Materia Medica; M. Collins, Medieval Herbals: The Illus- 
trative Traditions (London and Toronto, 2000), esp. chap. 3, "The Illustrated Arabic Herbals."

24. Quite a lot of work has been done on so-called Kufic script. See F. Déroche, Les manuscrits du Coran, aux origines de la calligraphie coranique, 2 vols. (Paris: Bibliothèque nationale de France, 1983-85); idem, The Abbasid Tradition: Qur'ans of the 8 th to the 10th Centuries AD, The Nasser D Khalili Collection of Islamic Art, vol. 1 (London: The Nour Foundation, 1992); F. Déroche and F. Richard, eds., Scribes et manuscrits du Moyen-Orient (Paris: Bibliothèque nationale de France, 1997); F. Déroche and S. Noja Noseda, Sources de la transmission manuscrite du texte coranique (Lesa: Fondazione Ferni Noja Noseda, 1998-); F. Déroche, ed., Manuel de codicologie des manuscits en écriture arabe (Paris: Bibliothèque nationale de France, 2000); F. Déroche, Le livre manuscrit arabe: Préludes à une histoire (Paris: Bibliothèque nationale de France, 2005). However, there has been far less study of the other scripts, and scholarly terminology in this regard is consequently rather limited. A good survey of the problems linked to this issue (even though more specifically for Persian manuscripts) is M. I. Waley, "Problems and Possibilities in Dating Persian Manuscripts," in F. Déroche, ed., Les manuscrits du Moyen-Orient: Actes du Colloque d'Istanbul 1986 (Istanbul and Paris, 1989), 7-15, especially 12-13. See also A. Contadini, "Travelling Pattern: A Qur'ānic Illumination and Its Secular Source" in S. Canby, ed., Safavid Art and Architecture (London: British Museum Press, 2002), 58-66, esp. n. 24. Among the relatively little written on nask $h$, see J. Raby, "The Nayrizi Tradition: Naskh in Safavid and Qajar Iran," in N. F. Safwat, The Ant of the Pen, The Nasser D Khalili Collection of Islamic Art, vol. 5 (London: The Nour Foundation, 1996), 212-27; D. Roxburgh, "On the Transmission and Reconstruction of Calligraphy: Ibn al-Bawwab and History," Studia Islamica 96 (2003): 39-53.

25. As examples, one may cite in this connection the following manuscripts: (1) an al-Sufi dated 400 (1009) in the Bodleian Library, Oxford (Narsh 144), for which see 17.12 above: (2) another in Qatar dated 519 (1125), for which see n. 3 above; (3) another in the Bodleian (Hunt 212), dated 566 (1171) and probably produced in Mosul, for which see J. Uri, Bibliothecae Bodleianae codicum manoscriptorum orientalium, 2 vols. in 1 (Oxford, 1787), pt. 1 (vol. 1), no. DCCCXCIX, 195, where the manuscript is misdated to 966 (1558) (see also $n .5$ above); Holter, "Die islamischen Miniaturhandschriften," 4, entry h, where the dating follows Uri's incorrect reading; E. Wellesz, "Islamic Astronomical Imagery: Classical and Bedouin Tradition," Oriental Art 10, 2 (1964): 89-91; Sezgin, Geschichte des arabischen Schriftums, 214; Savage-Smith. "Celestial Mapping," 52, fig. 2.34; Savage-Smith, "Islamic Tradition of Celestial Mapping," 14-15 and fig. 8; (4) another in the Topkapı Sarayı Library, Istanbul (Ahmet III, 3493), which was copied between 10 Muharram and 12 Safar 525 (December 14,1130 -January 15, 1131) by Wathiq b 'Ali b. 'Umar b. al-Husayn, known as Abu 'l-Shawqi, possibly in Mayyafariqin, for which see K. Holter, "Die Galen-Handschrift und die Makamen des Hariri der Wiener Nationalbibliothek," Jahrbuch der Kunsthistorischen Sammlungen in Wien N.F. 9 (1937): 36, no. 1: Hoiter, "Die islamischen Miniaturhandschriften," 3, no. 2, where the ms. no. is mistakenly given as 2493; Wellesz, "An Early al-Süfi Manuscript," 20-21; J. M. Rogers, Topkapr Sara)
Museum: Albums and Illustrated Manuscripts, 29-30, nos. 1-6 and color pls. 1-6; (5) another in Istanbul, in this case in the Sülevmanive Library (Fatih 3422), dated 529 (1134-35) and made in Mardin, its scribe signing himself as 'Abdallah b. Abd al-Jabbar b. al-Rahim b. Sadaqa b. 'Ali b. Yusuf b. Nassam al-Jabali, for which see Ettinghausen, Arab Painting, 162; Holter, "Die Galen-Handschrift," 36, no. 2; Holter, "Die islamischen Miniaturhandschriften," 3, no. 3; Wellesz, "An Early al-Süfi Manuscript," 22-23; R. Ward, "Evidence for a School of Painting at the Artuqid Court," in J. Raby, ed., The Art of Syria and the Jazira 1100-1250, Oxford Studies in Islamic Art, vol. 1 (Oxford, 1985), 80; (6) another in the Berlin Staatsbibliothek (5658), dated 630 (1233) and produced in Mosul, its scribe being Farah b. 'Abdallah al-Habbashi, for which see W. Ahlwardt, Die Handschriften-Verzeichnisse der Königlichen Bibliothek zu Berlin: Arabische Handschriften, 10 vols. (Berlin, 1893), vol. 5, no. 5658; also, a copy of pseudo-Galen's Kitäb al-Dinjāq dated to 1199, now in the Bibliothèque nationale, Paris (ms. arabe 2964), for which see W. M. le baron de Slane, Catalogue des mamuscrits arabes (Paris: Imprimeries Nationale, 188395), 530; B. Farès, "Le livre de la Theriaque," Art Islamique 2 (1953): 1-56; Ettinghausen, Arab Painting, 83-86, 91-92 and color pl. on 84-85; A. S. Melikian-Chirvani, "Matériaux pour servir à l'histoire de la peinture persane: Trois manuscrits de l'Iran seldjoukide," Arts asiatiques 16 (1967), 3-16, 25-30, and figs. 1-2, 7-12, who attributes the manuscript to Seljuq Iran; Hunt, "Commissioning," 132; James, Arab Painting, 22; N. Nassar, "Saljuk or Byzantine," 85, 86, 88-90, 92, 94, 96, and figs. 1, 2, 4; C. Vaudour and J. Mouliérac, eds., A l'ombre d'Avicenne: La médecine au temps des califes, catalogue of the exhibition held at the Institut du monde arabe (Paris, 1996), 156, no. 87 and color pls. on 102-3, 156-57, 230, 233; O. Pancaroğlu, "Socializing Medicine: Illustrations of the Kitāb al-Diryãq," Muqarnas 18 (2001): 155-72; J. Kerner. "Art in the Name of Science: Illustrated Manuscripts of the Kitn̄h al-rimāa" (PhD diss. New York Universitv. 2004): idem. "Art in the Name of Science: The Kitäb al-disyag in Text and Image," in Contadini, ed., Arab Painting.

26. The bulk of the manuscript is in the Süleymaniye Library of Istanbul (Ayasofya 3703), with a number of its folios dispersed in other collections. The colophon names the scribe as 'Abdallah b. al-Fadl, and gives the date Rajab 621 (JulyAugust 1224). See Holter, "Die islamischen Miniaturhandschriften," 11-12, no. 27; Buchthal, Kurz, and Ettinghausen, "Supplementary Notes," 151-52, no. 27; 20-34; and 42, figs. 4-31; Grube, "Materialien zum Dioskurides Arabicus," 172-78 and figs. 1-4; Ettinghausen, Arab Painting, 87-90 and color pls. on 87, 89; and James, Arab Painting, 20. For a discussion of certain folios, see B. Gray, "Persian Miniatures," The British Museum Quarterly 9 (1935): 88-90, entry no. 58 and pl. XXIV; F. E. Day, "Mesopotamian Manuscripts of Dioscorides," Bulletin of the Metropolitan Museum of Art 8 . 49-50 (May 1950): 271-280; Arts Council of Great Britain. The Arts of Islam, catalogue of an exhibition at the Hayward Gallery, London (London, 1976), 324, nos. 520-21; Sadek. Arabic Materia Medica, 14, no. 11; and Touwaide, Farmacopea Araba Medievale, 254, no. 194, and color pls. on 46, 82, 85, $87,92,98-99,254$.

27. Vatican Library, Syr. no. 559. See G. de Jerphanion, Les miniatures du manuscrit syriaque no. 559 de la Bibliothèque vaticant 
(Vatican: Biblioteca apostolica vaticana, 1940): H. Buchthal and O. Kurz, A Hand List of Illuminated Oriental Christian Manuscripts (London, 1942), 21-22, no. 63; J. Lerov, Les Manuscrits syriaques à peintures conservés dans les bibliothèques d'Europe et d'Orient. (Paris: Paul Geuthner, 1964), 280-302, pls. 7092, 94-99, and color pl. between 4 and 5; Ettinghausen, Arab Painting, 98 and color pl. on 94; Hunt, "Manuscript Production," 160. The date of this manuscript has been disputed at times, but no convincing argument has vet been put forward for a revision of the 1220 date.

28. British Library, Add. Ms. 7170. See W. Wright, Catalogue of the Syriac Manuscripts in the British Museum Acquired since the Year 1838, 3 vols. (London, 1870-72), vol. 3, 1204; A. Mingana, Catalogue of the Mingana Collection of Manuscripts: Now in the Possession of the Trustees of Woodbrooke Settlement. Selly Oak. Birmingham, 4 vols. (Cambridge, Eng., 1933-63), vol. 1, cols. 1127-28, no. 590; H. Buchthal, "The Painting of the Syrian Jacobites and Its Relation to Byzantine and Islamic Art," Syria 20 (1939): 136-50; Buchthal and Kurtz, Hand List, 13-14. no. 19; Leroy, Manuscrits syriaques, $302-13$ and pls. 70-78, 80-99; H. C. Evans and W. D. Wixom, eds., The Glony of Byzantium: Art and Culture of the Middle Byantine Era A.D. 8431261, catalogue of an exhibition held at the Metropolitan Museum of Art (New York, 1997), 385, no. 254 and color pl. 254; L. A. Hunt, "Christian-Muslim Relations in Painting in Egvpt of the Twelfth to Mid-Thirteenth Centuries: Sources of Wallpainting at Deir as-Suriani and the Illustration of the New Testament Ms. Paris, Copte-Arabe 1/Cairo, Bibl. 94," in idem, Byzantium, Eastem Christendom and Islam, vol. 1, 262 and figs. 22-24; L. A. Hunt, "Cultural Transmission: Illustrated Biblical Manuscripts from the Medieval Eastern Christian and Arab Worlds" in idem, Byzantium, Eastern Christendom and Islam, vol. 2, 11; Hunt, "Manuscript Production," $160-62$ and fig. 6.

29. Contadini, The Kitäb Nát al-Hayāwān.

30. The latter is in St. Petersburg. Academv of Sciences. Ms. S 23. See Holter. "Islamischen Yiniaturhandschriften," 1,314, no. 32; Buchthal, Kurz, and Ettinghausen, "Supplementary Notes," 153, no. 32; D. S. Rice, "The Oldest Illustrated Arabic Manuscript," Bulletin of the School of Oriental and African Studies 22 (1959): 215, 217, 218, and pl. 1; Ettinghau- sen, Arab Painting, 104-11 and color pls. on 106-8, 111-13; O. Grabar, "Pictures or Commentaries: The Illustrations of the Maquamät of al-Harīin," in Studies in Art and Literature of the Near East in Honor of Richard Ettinghausen, (Salt Lake City, 1974), 97-98 and pl. 3; D. James, "Space-Forms in the Work of the Baghdād Maqāmāt Illustrators, 1225-58," Bulletin of the School of Oriental and African Studies 37 (1974): 305-6. $314-$ 16 and fig. 4; James, Arab Painting, 20-22: O. Grabar, The Illustrations of the Maqamat (Chicago: University of Chicago Press, 1984), 11, no. 4 and subsequent references in discussions of individual maqāmāt; Y. A. Pétrosvan, ed., De Bagdad à Ispahan: Manuscrits islamiques de la Filiale de Saint-Pètersbourg de l'Institut d'Etudes Orientales, Académie des Sciences de Russie, catalogue of an international exhibition held 199495 (Paris: Fondation ARCH, 1994), 116-27, which includes 16 color reproductions.

31. James, Arab Painting, 20; A. Contadini, "Islamic Manuscripts and the ARCH Foundation," Apollo (Feb. 1995): 29.

32. Paris, Bibliothèque nationale, Ms. Arabe 5847. This manuscript is dated 6 Ramadan 634 (3 May, 1237), and was both written and illustrated by Yahya b. Mahmud b. Yahya b. Abu l-Hasan b. Kuwarriha al-Wasiti. See E. Blochet, Calalogue des Manuscrits arabes des nouvelles acquisitions (1884-1924) (Paris: Editions Ernest Leroux, 1925), 125-26; E. Blochet, Les enluminures des manuscrits orientaux-turcs, arabes, persans - de ! a Bibiotheque nationale, Editions de la Gazette des Beaux-Arts (Paris, 1926), 56-58 and pls. X-XIII; "Die Islamischen Miniaturhandschriften," 13, no. 31; Buchthal, Kurz, and Ettinghausen, "Supplementary Notes," 152-53, no. 31; Buchthal, "Early Islamic Miniatures," 35-37 and figs. 32-33, 37-38, 40; Rice, "The Oldest Illustrated Arabic Manuscript," 215, 216-18, and pl. III; Ettinghausen, Arab Painting, 104, 11424 and col. pls. on 114, 116-19, 121-22; O. Grabar, "Pictures or Commentaries." 85-86, 87-88, 92, 94, 97-99, pls. III, V, VIII, XI; James, "Space-Forms," 304-6, 307-9, 313-15, 316-17 and fios. 1. 5: James, Arab Painting. 20-22: Grabar. Illustrations of the Maqumat. 10-11. no, 3 and subsequent teferences in discussions of individual maquamat: for the frontispieces of this manuscript see Hoffman, "The Author Portrait," 15 and figs. $6 \mathrm{a}-\mathrm{b}$. 


\section{Offprint from: \\ MUQARNAS}

An Annual on the Visual Culture of the Islamic World Volume 23 (2006)

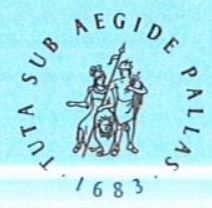

B R I L L

LEIDEN

2006 